\title{
Sauropterygian remains from the Middle Triassic of Villány, Hungary-new information on the aquatic reptile fauna of Tisza Megaunit (Triassic southern Eurasian shelf region)
}

\author{
Martin Segesdi ${ }^{1,2,3}$ (D) Attila Ösi ${ }^{1,2,3}$
}

Received: 29 May 2020 / Revised: 25 August 2020 / Accepted: 17 December 2020 / Published online: 3 March 2021

(C) The Author(s) 2021

\begin{abstract}
Sauropterygia was a diverse clade of secondary aquatic reptiles, which represented one of the most important vertebrate groups in the shallow marine communities during the Triassic. However, despite the long history of collection and examination of sauropterygian remains, previous studies have indicated that the fossil record of this group is incomplete, making the understanding of their palaeobiogeographic relations difficult. Here we describe new sauropterygian remains from the Middle Triassic (Ladinian) Templomhegy Dolomite Member (Villány, southern Hungary), which were unearthed during systematic fieldwork of previous years. Among several non-diagnostic sauropterygian remains, this material contains isolated bones belonging to Nothosaurus sp., Simosauridae indet. and a small-sized nothosaurid. The known faunal composition from Villány is similar to what was described from the Middle Triassic of the Germanic Basin and Bihor Mountains (northwestern Romania). Besides isolated elements, a probably associated skeleton of a small-sized eosauropterygian specimen of unknown affinities is also reported here. This locality widens our knowledge on Triassic sauropterygian distribution and provides new information about the previously not well-known Middle Triassic vertebrate fauna of the one-time southern Eurasian shelf region.
\end{abstract}

Keywords Sauropterygia $\cdot$ Nothosaurus $\cdot$ Simosauridae $\cdot$ Middle Triassic $\cdot$ Tisza Megunit

\section{Introduction}

Sauropterygia Owen, 1860 represents one of the most successful aquatic sauropsid groups from the Mesozoic Era. It was a monophyletic clade of secondary aquatic diapsids (Rieppel 2000; Neenan et al. 2013) with high ecological diversity and numerous adaptations to life in an aquatic environment (Storrs 1993; Rieppel 2000, 2002; Houssaye 2009; Araújo and Correia 2015; Klein et al. 2016). The two lineages

Martin Segesdi

martinsegesdi@gmail.com

Attila Ösi

hungaros@gmail.com

1 Department of Paleontology, Eötvös Loránd University, Budapest, Hungary

2 Department of Paleontology and Geology, Hungarian Natural History Museum, Budapest, Hungary

3 Eötvös Loránd University Dinosaur Research Group, Budapest, Hungary of Sauropterygia, namely Placodontia Cope, 1871 and Eosauropterygia Rieppel, 1994a, can be characterised with different body plans, habitats and ecological niches (Rieppel 2000). Placodonts were mostly durophagous, benthic-feeding aquatic reptiles of the shallow-marine realms, where they most probably consumed sessile or benthic hard-shelled or soft invertebrates, in addition to plant material in some cases (Rieppel 1995, 2000, 2002; Scheyer et al. 2012). In contrast, eosauropterygians hunted in the water column for soft or hardshelled invertebrates besides other vertebrates, including aquatic reptiles and fish (Rieppel 2000, 2002).

The majority of Triassic sauropterygians were most probably near-shore dwellers (Klein et al. 2016; Neenan et al. 2017), and their habitat was confined to the coastal environments, intraplatform basins and shallow epicontinental seas (Rieppel 1997, 2000). Their Triassic distribution can be divided into three main regions: the western Tethyan province (epicontinental Germanic Basin, Alpine Triassic with the southern Alps-Transdanubian platform, the Mediterranean region, shelf areas of western Tethys); the western Pacific province (or eastern Tethyan province - southeastern Asia); and the eastern Pacific province (western part of North America) (Rieppel 
and Hagdorn 1997; Rieppel 1999, 2000; Bardet et al. 2014; San et al. 2019). Nevertheless, despite the long history of the study of sauropterygian remains, previous studies pointed out that the fossil record of this group is affected with a considerable incompleteness, which makes understanding their palaeobiogeographic relations and origin problematic (Rieppel 1999).

Despite the high amount of Triassic rocks and welldocumented outcrops, fossils of tetrapods are rare in Hungary (and also in the Carpathian-Pannonian Basin) from this period, but isolated remains were documented from different localities (Ösi et al. 2013). A fragment of an eosauropterygian mandible with in situ teeth is known from Felsöörs, from the Middle Triassic Vászoly Formation of the Balaton Highland (Ösi et al. 2013). Recently, an isolated fragmentary eosauropterygian dorsal rib was found along the main road in debris, between Balatonfüred and Aszófö (A. Ösi pers. comm.). Maybe the most important Triassic vertebrate finding is the associated Placochelys placodonta Jaekel, 1902a material from Veszprém (Bakony Mountainsprobably from the Carnian Veszprém Marl Formation) (Jaekel 1901, 1902a, 1902b, 1907; Rieppel 2000). A single Nothosaurus Münster, 1834 vertebra is known from Hetvehely (lower-middle Anisian Lapis Limestone Formation) from the Mecsek Mountains (Bodor and Makádi 2016), and isolated nothosaur teeth were also mentioned from this region (Ösi et al. 2013). After the geologist Emilia Pozsgai discovered some teeth, vertebrae, and limb elements in the Middle Triassic beds exposed in a construction site on Somssich Hill (Villány-Southern Hungary), systematic excavations started in 2012 (Ösi et al. 2013). Since then, these vertebrate-bearing Triassic layers have provided thousands of vertebrate fossils - including isolated teeth and bone remains of different fish, sauropterygians (placodonts, nothosaurs), vertebrae of Tanystropheus von Meyer, 18471855 , along with a most probably associated eosauropterygian specimen composed of postcranial elements, and other fragments of undetermined sauropsids (Ösi et al. 2013; Segesdi et al. 2017; Szabó et al. 2019; Gere et al. 2020; Ösi et al. 2020).

Concerning the present work, a sauropterygian material described from the Bihor Mountains (northwestern Romania, part of the Apuseni Mountains) is highly interesting, because the Bihor Mountains are situated on the same tectonic unit as Villány (Tisza Megunit), and were most probably located in a similar palaeogeographical region, southwards from the Bohemian Massif, during the Triassic (Pozsgai et al. 2017). The revealed Peștiș Shale Member of Lugaș Formation has provided hundreds of vertebrate fossils (Patrulius et al. 1971; Jurcsák 1973, 1987; Patrulius et al. 1979; Venczel 1998). The Middle Triassic — probably late Anisian (Jurcsák 1987; Iordan 1993; Posmosanu 2013) - material consists of isolated and disarticulated skeletal elements (Posmosanu 2013). Based on the reports of Jurcsák, sauropterygians are represented by different placodonts, and also by several eosauropterygians including Simosaurus Meyer, 1842 and two Nothosaurus species (Jurcsák 1987; Posmosanu 2008). Jurcsák reported two species of Nothosaurus: the middle-sized Nothosaurus mirabilis Münster, 1834 and a smaller species, which was described based on a fragmentary skull (Nr.inv. 7653.) from Peştiş, (Jurcsák 1973) as Nothosaurus cf. procerus Schroeder, 1914. Later Jurcsák decided to describe it as a new species: Nothosaurus transsylvanicus Jurcsák, 1976. However, according to Rieppel et al. (1999), the fragmentary skull described by Jurcsák as $N$. transsylvanicus is very similar, maybe identical, to Nothosaurus marchicus Koken, 1893. Moreover, in the revisional work of Rieppel and Wild (1996), N. procerus has been assigned as a junior synonym of $N$. marchicus, and probably the species described by Jurcsák represents the latter species, but this material needs further revision. Besides this material, Čerňanský et al. (2018) reported a Pachypleurosauria indet. skeleton from Slovakia, from the Middle Triassic of the Western Carpathians (Fatric Unit), a unit which was also situated in a relatively close palaeogeographical region to Villány.

Our work aims to report and describe the new Middle Triassic sauropterygian aquatic reptile findings unearthed during the fieldwork of previous years in Villány. The new material provides essential information on the faunal composition of the site, completing the results of previous studies (see Ösi et al. 2013).

\section{Material and methods}

The material discussed herein contains isolated elements collected in Villány (southern Hungary) from the Middle Triassic Templomhegy Dolomite Member. The remains were excavated at a construction site on Somssich Hill, 200-300 m southwestern from the railway station of Villány (Fig. 1). The southern part of the site is an unfinished basement and exposes the important bone-bearing layers (dipping to south with $40-50^{\circ}$ ) of the Templomhegy Dolomite Member (upper part of Csukma Dolomite Formation). In the southwestern part of this hollow, the Mészhegy Sandstone Formation unconformly overlies the Templomhegy Dolomite (Ösi et al. 2013; Botfalvai et al. 2019). The remains were prepared mechanically and all specimens are housed in the Hungarian Natural History Museum (Vertebrate Collection of the Paleontology and Geology Department). Supplementary material contains a list of described specimens. Measurements were taken with calippers and tape measure, and photos were edited using Adobe Photoshop CS6. The height of the neural spines was measured from the roof of the neural canal, if the condition of the specimen allowed it.

Anatomical terminology follows the standard names used in previous works written on sauropterygians (e.g. Rieppel 

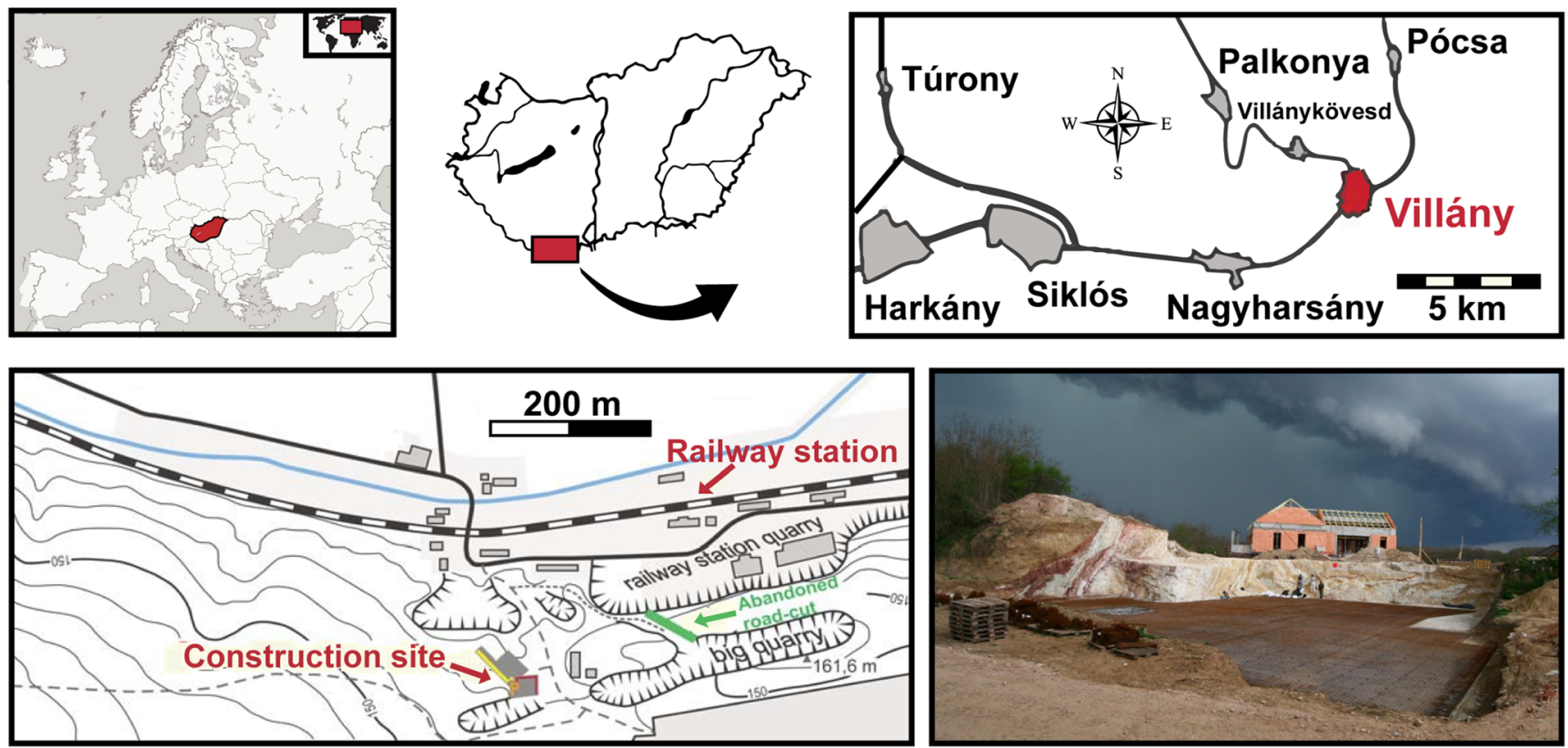

Fig. 1 Location and photo of 'Construction site' vertebrate locality in Villány, southern Hungary (map modified after Ösi et al. 2013)

2000) and anatomical directions follow Smith and Dodson (2003).

\section{Geological settings}

The Villány Hills are situated on the Tisza Megaunit, which used to be part of the southern passive margin of the European Plate during the first half of the Mesozoic: it took part in the forming of shelf areas of the northwestern Tethys near to the Germanic Basin (Csontos and Vörös 2004; Haas and Péró 2004). Pozsgai et al. (2017) provided exact informations about the paleo-position of this region and indicated that it was located southwards to the Bohemian Massif during the Triassic (Fig. 2), which means that the Villány area was eastwards from the Germanic Basin. Nowadays, the vast majority of this megaunit is covered by Cenozoic sediments; however, it is exposed in the Slavonian Inselbergs (Croatia), Mecsek Mountains and Villány Hills (southern Hungary), in the Apuseni Mountains (northwestern Romania) and near the Eastern and Southern Carpathians (Bleahu et al. 1994; Csontos and Vörös 2004). The parts of the megaunit, namely Mecsek-Szolnok, Villány-Bihor and BékésCodru Units (Csontos and Vörös 2004), represent different zones of the late passive margin (Fig. 2), where the sediments reflect variant palaeograhic positions (Pozsgai et al. 2017; Botfalvai et al. 2019).

The Early and Middle Triassic sediment successions of this area show close generic similarities with the Germanic type sediments (Nagy and Nagy 1976; Török 1997, 1998). During the Early and the beginning of Middle Triassic, terrestial and coastal clastic sedimentation (Bundsandstein facies) was typical on the Villány-Bihor Unit. Later, (at the beginning of Anisian) evaporites formed on the tidal flats and surrounding sabkha areas under arid climate (Röt facies). Following this period (during Anisian-Ladinian), carbonatic sedimentation dominated (Muschelkalk facies) and an expansive homoclinal carbonate ramp developed (Török 1997). This ramp, on the passive continental margin, with its uniform subsidence rate can be characterised with high production of carbonatic mud and the lack of reef biota (Török 1998, 2000). The Late Triassic succession was siliciclastic, with closer affinities to the Carpathian Keuper facies (Bleahu et al. 1994; FeistBurkhardt et al. 2008). The formations exposed at the 'Construction site' vertebrate locality represent the uppermost strata of the Muschelkalk carbonate ramp and a thin clastic Keuper (Bérczi-Makk et al. 2004; Vörös 2009).

The bone-bearing Templomhegy Dolomite Member (Fig. 3) is the upper part of the Csukma Dolomite Formation. This formation overlies the Zuhánya Limestone Formation, which formation considered to be middle-upper Anisian (upper Pelsonian) in age with conodont-based stratigraphy, based on samples taken from the Peterd-1 borehole (from the Villány Hills) (Bóna 1976; Kovács et al. 2005). The Templomhegy Dolomite is covered by the siliciclastic (sandstone and claystone) Mészhegy Sandstone Formation, which was described variously by different aouthors: while Vörös (1972) considered the formation as fluvio-lacustrine, RálischFelgenhauer (1985), Török (1998) and most recently Ösi et al. (2013) and Botfalvai et al. (2019) diagnosed it as shallow marine. Based on the palynomorph content of its basal layers, the age of the Mészhegy Sandstone is Carnian (Ösi et al. 2013; Pozsgai et al. 2017). 

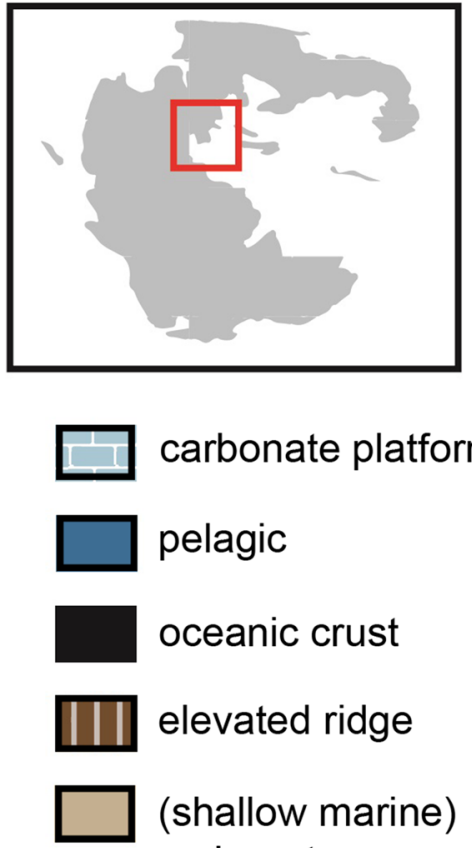

carbonate platform

pelagic

oceanic crust

elevated ridge

(shallow marine) carbonate ramp

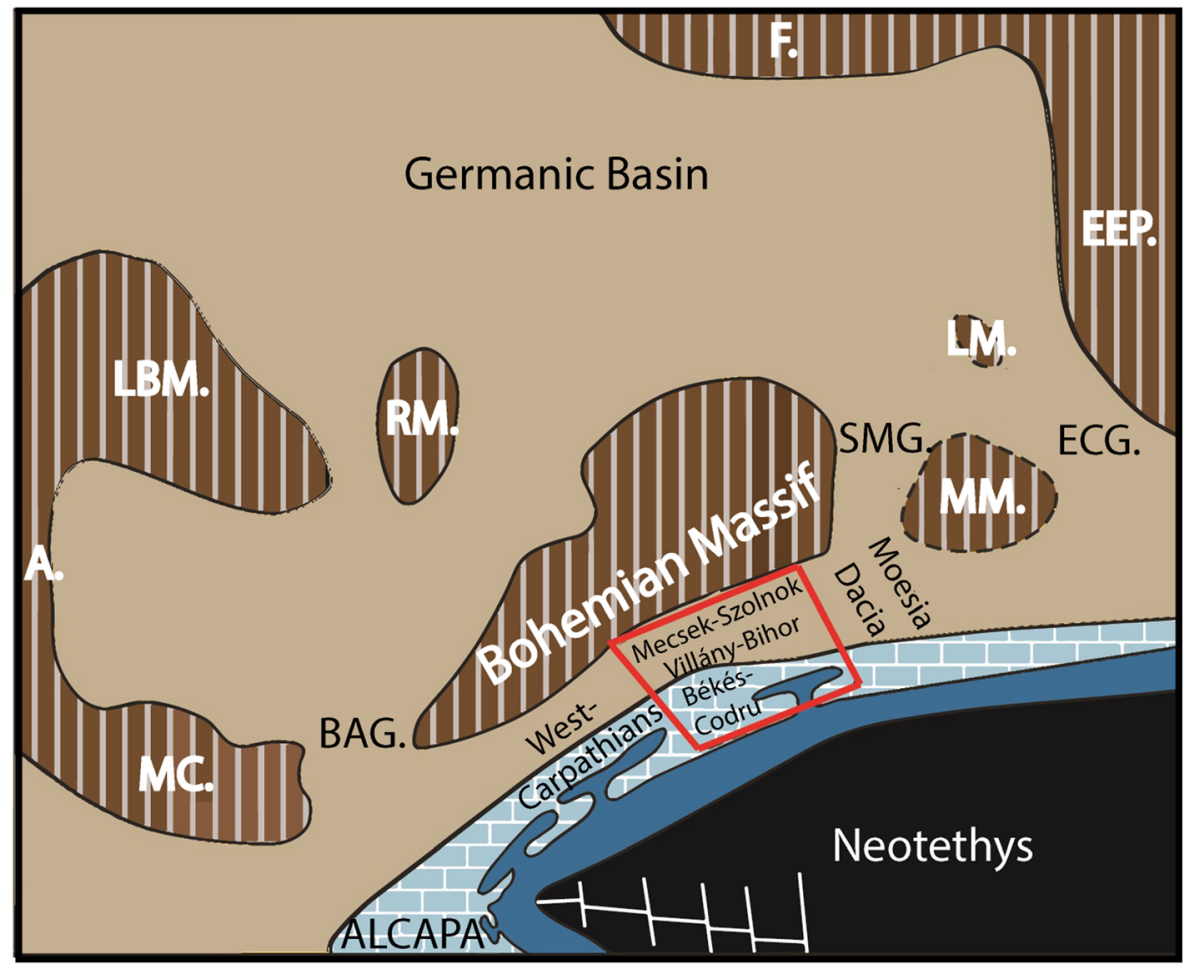

Fig. 2 Middle Triassic position of Tisza Megaunit (in red square) and the surrounding areas. ALCAPA composite terrane (Alps-CarpathiansPannonian) involves the parts of Penninic, Austroalpine, Inner and Central Western Carpathian and Pelso composite units (modified after Pozsgai et al. 2017 in which palaeotectonic map is based on Szulc

2000; Haas and Péró 2004; Schmid et al. 2008). LBM, London-Brabant Massif; A, Armorican Massif; MC, Massif Central; RM, Rhenish Massif; BAG, Burgundy-Alemannic Gate; F, Fennoscandia; EEP, East-European Platform; LM, Lysogóry Massif; SMG, Silesian-Moravian Gate; MM, Malopolska Massif; ECG, East-Carpathian Gate

The fossil content of the Templomhegy Dolomite Member is very poor: besides the bones, only some rare crinoids, foraminifera, bivalves and brachiopods have been found here (Nagy and Nagy 1976; Rálisch-Felgenhauer 1981; RálischFelgenhauer and Török 1993; Török 1998; Bérczi-Makk et al. 2004). Since none of these findings are true age diagnostic fossils, the inferred Ladinian age for the bonebeds of Templomhegy Dolomite Member is only based on its stratigraphic position: between the middle-upper Anisian (Pelsonian) Zuhánya Limestone and the Carnian Mészhegy Sandstone Formations. However, it must be noted that without age indicators from the bone-bearing layers, the potential age of the locality ranges between the uppermost Anisian (Pelsonian or Illyrian) and lower Carnian. The Ladinian age was also suggested previously, based on the described vertebrate material (Ösi et al. 2013).

The depositional environment of the Templomhegy Dolomite Member was determined as subtidal to peritidal zone on the inner ramp; most probably the sediments were deposited in a shelf lagoon (Rálisch-Felgenhauer and Török 1993; Török 2000; Ősi et al. 2013; Botfalvai et al. 2019). In this environment, the alternation of sediments was most probably controlled by the sea-level fluctuations, and the recurrent palaeosol layers indicate the periodical subaeral exposures (Botfalvai et al. 2019). The Templomhegy Dolomite Member at the vertebrate site consists of four lithofacies: dolomite-; dolomarl-; sandstone-; and reddish calcareous mudstone, claystone (Botfalvai et al. 2019). The dolomite beds and layers are originated from a shallow, restricted lagoonal environment, while the dolomarl with its higher siliciclast content refers to an intermediate area between the intertidal and subtidal zones. The vertebrate fossils are more common in the marly layers (Fig. 3 ), especially between the 14th and 24th layers (see Botfalvai et al. 2019). The richest bone-bearing beds were most likely deposited in a period with episodically increased terrigenous influx, most probably due to the enhanced precipitation runoff and/or relative sea-level fall (Botfalvai et al. 2019). The red calcareous mudstone claystone layers are palaeosoil horizons, caused by the subaerial exposure during low sea level phases; however, the origin of the sandstone (sandy mudstone) is not fully solved yet (Botfalvai et al. 2019).

\section{Systematic palaeontology}

Sauropsida Huxley, 1864

Sauropterygia Owen, 1860

Eosauropterygia Rieppel, 1994a 
a

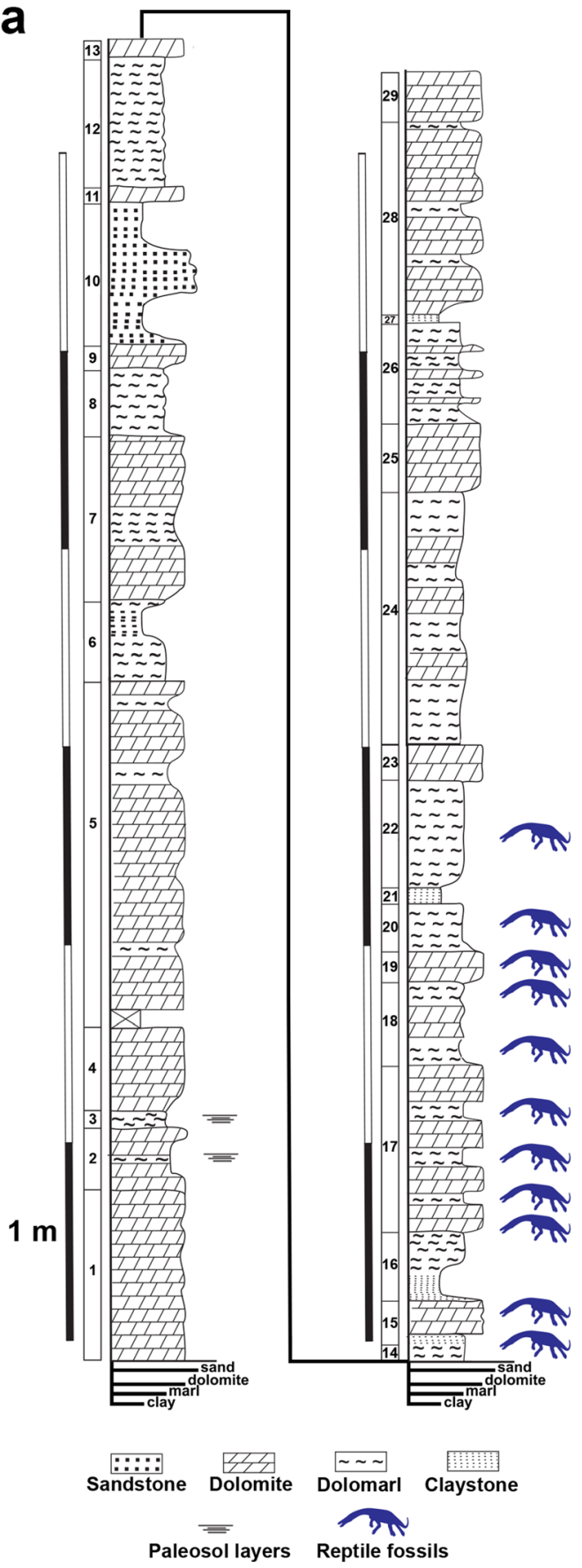

b

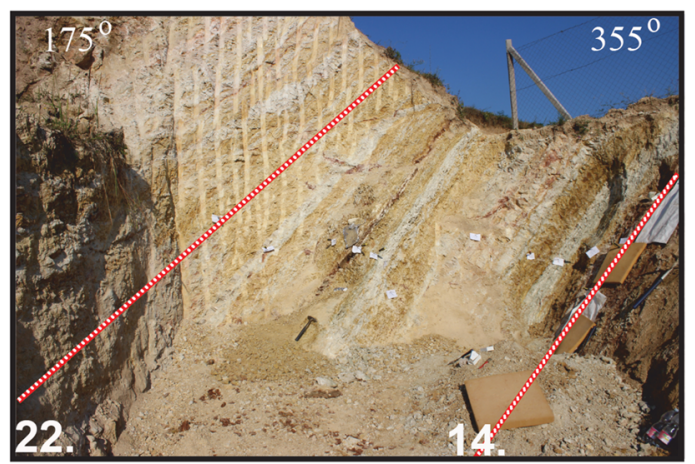

Fig. 3 Schematic stratigraphy of the exposed bone-bearing Middle Triassic beds of the 'Construction site' vertebrate locality in Villány, southern Hungary. a Exposed strata of Templomhegy Dolomite Member at the site (modified after Botfalvai et al. 2019). b Picture of the most important bone-bearing layers (between 14th and 22th, within dotted lines)

Nothosauroidea Baur, 1889

Nothosauria Baur, 1889

Nothosauridae Baur, 1889

Nothosaurus Münster, 1834

Nothosaurus sp. Münster, 1834

(Fig. 4)

Material: dorsal vertebra PAL 2019.171.1.; isolated neural arches PAL 2019.172.1., PAL 2019.175.1., PAL 2019.176.1., PAL 2019.177.1.

Locality and Horizon: Villány (southern Hungary), construction site on Somssich Hill, Csukma Dolomite Formation (Templomhegy Dolomite Member), Middle Triassic (probably Ladinian) (Ösi et al. 2013; Botfalvai et al. 2019).

Description: PAL 2019.171.1. (Fig. 4(a-c)) represents a dorsal vertebra with very tall neural spine (overall height is $135 \mathrm{~mm}$ ). The neural arch is fused with the centrum along the neurocentral suture. The platycoelous vertebral centrum holds one foramen on both sides, positioned asymmetrically, the centrum is not constricted. The height of the neural arch cannot be measured correctly because it is broken and compressed, but it is still distinctly tall $(87 \mathrm{~mm})$. The largest width of the transverse processes is $54 \mathrm{~mm}$. They are laterally overhanging the centrum and display a slender morphology. Zygosphene is present but broken, and the zygantrum is high and narrow with thin bony septum situated medially inside. There are no infrapre- and infrapostzygapophyses. The ventral side of the transverse processes is almost on the same level as the dorsal side of the vertebral centrum. Pre- and postzygapophyses are swollen (pachyostotic). The postzygapophyses are positioned dorsally and their lateral top is higher above the level of the transverse processes. The articular facets of pre- and postzygapophyses form an angle of $20-25^{\circ}$ with the horizontal. The neural canal is narrow, the width of the vertebral centrum is $27 \mathrm{~mm}$, while the height is $30 \mathrm{~mm}$.

PAL 2019.172.1. (Fig. 4(d)) is an isolated dorsal neural arch fragment, having a similar zygosphene-zygantrum articulation, swollen zygapophyses and a very high neural spine in relatively good condition. The anterodorsal region of the neural spine shows a spongy area; moreover, the top of the spine holds a saddle-shaped depression, with a smooth inner surface, probably representing an insertion for muscular tendons.

PAL 2019.175.1. (Fig. 4(e-g)) is an isolated neural arch with a similar morphology like PAL 2019.171.1. and PAL 2019.172.1.; however, this arch displays a low neural spine which tilts anteriorly. The width of the slender transverse 


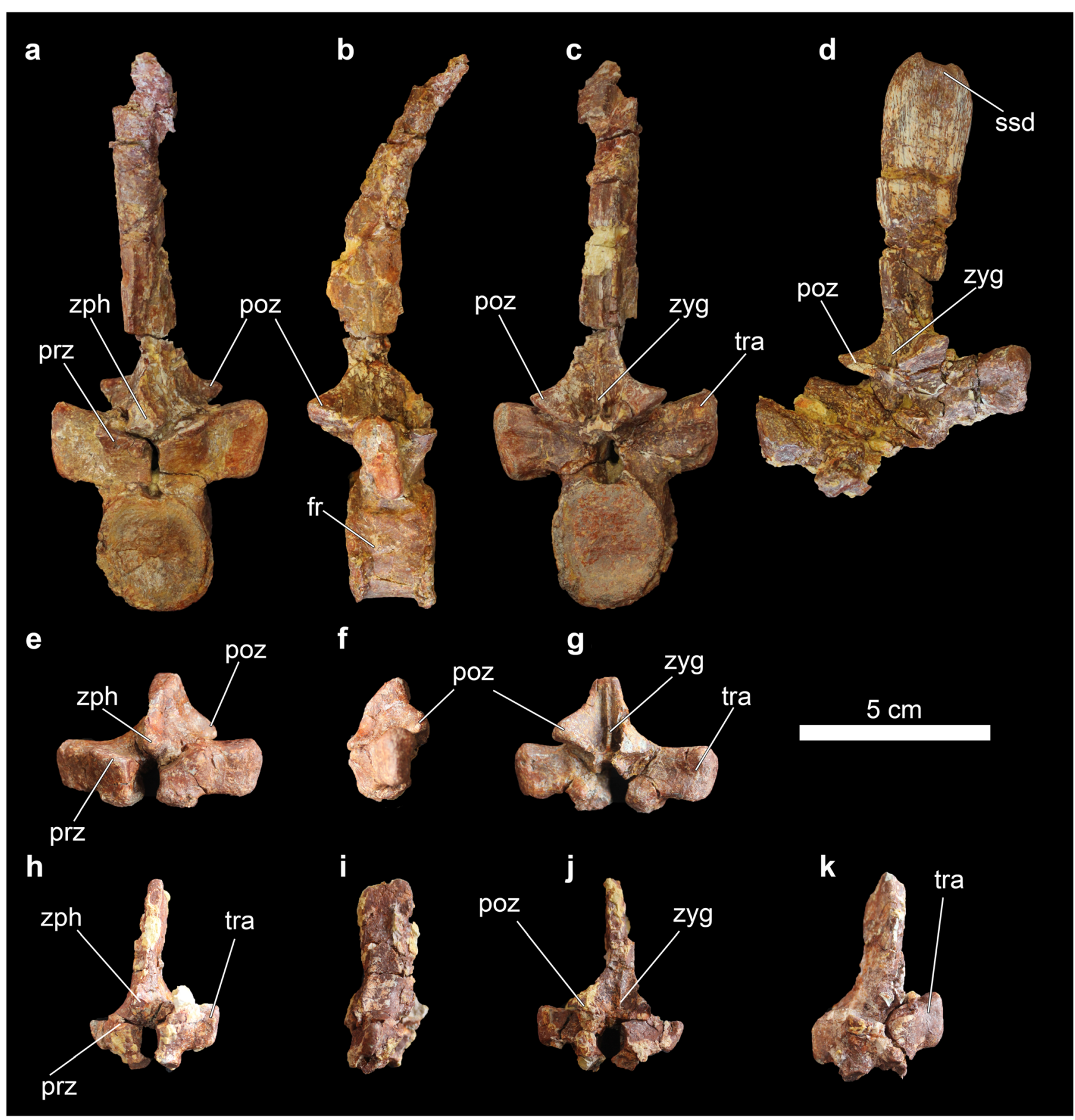

Fig. 4 Nothosaurus sp. vertebrae from the Middle Triassic 'Construction site' of Villány, southern Hungary. a-c Dorsal vertebra (PAL 2019.171.1.) in anterior, right lateral and posterior view. d Isolated dorsal neural arch (PAL 2019.172.1.) in posterior view. e-g Isolated neural arch (PAL 2019.175.1.) in anterior, left lateral and posterior

processes is $65 \mathrm{~mm}$, and the height of the neural spine is only $27 \mathrm{~mm}$. Pre- and postzygapophyses are swollen and their articular facets form an angle of $20^{\circ}$ with the horizontal. Zygosphene and zygantrum are present, and the latter holds a thin bony septum situated medially inside, the neural arch lacks infrapreand infrapostzygapophyses. The right postzygapophysis is view. h-j PAL 2019.176.1. neural arch in anterior, right lateral and posterior view. k PAL 2019.177.1. in posterior view. Anatomical abbreviations: $f r$ foramen, poz postzygapophysis, $p r z$ prezygapophysis, ssd saddle-shaped depression, tra transverse process, zph zygosphene, zyg zygantrum

broken, the left is intact, shifted dorsally, and its lateral top is situated higher than the dorsal side of transverse processes. The transverse processes ventrally do not reach the level of the neural centrum.

PAL 2019.176.1. and PAL 2019.177.1. (Fig. 4(h-k)) are isolated neural arches with similar elongated neural spines 
with vertical striations on their lateral surface. They represent a smaller size class when compared to the above mentioned PAL 2019.171.1. and PAL 2019.172.1. They have slender and wide transverse processes; they only slightly increase in diameter, and pachyostotic pre- and postzygapophyses. Both of them display zygosphene-zygantrum articulation and lack infrapre- and infrapostzygapophyses. PAL 2019.176.1. has a 53-mm-tall neural spine and 36-mm transverse process width, while the height of PAL 2019.177.1. is $42 \mathrm{~mm}$ and the width of the transverse processes is $38 \mathrm{~mm}$.

Discussion: Based on the presence of zygosphene-zygantrum articulations, and the relatively short transverse processes, the dorsal vertebra PAL 2019.171.1. and the isolated neural arches belong to Eosauropterygia (Rieppel 1998, 2000). Among eosauropterygians with zygapophyseal pachyostosis, Nothosaurus mirabilis, N. tchernovi Haas, 1980 and N. haasi Rieppel, Mazin and Tchernov, 1999 are characterised by elongated, tall neural spines (Rieppel 2000; Liu et al. 2014). Although a well-developed bipartite zygosphene is one of the characters of nothosaurs (Rieppel and Wild 1996), due to the poor preservation of the specimens, this feature can not be discussed in detail. The Late Triassic Bobosaurus forojuliensis Dalla Vecchia, 2006 also exhibits highly elongated neural spines, but in the case of this species the vertebrae are more complex and display additional infrapre- and infrapostzygapophyses: features absent from the Villány specimens (Dalla Vecchia 2006). Furthermore, the distal end of slender transverse processes on all the mentioned neural arches only slightly increasing in diameter, which characters also present in Nothosauridae (Rieppel 1998, 2000). Remains of Pistosauridae Baur, 1887-1890 are different with the narrower zygapophyses, longer transverse processes, and the foramina on their constricted vertebral centra ('subcentral foramen') are situated symmetrically (Sues 1987; Sander et al. 1997). The postcranial material described as $N$. haasi represents a smaller size class with slender neural arches and distinctly shorter dorsal neural spines (Rieppel et al. 1999). The largest dorsal neural spines of the Villány specimens also exceed the size of what is typical for $N$. tchernovi; moreover, in the case of this species, the transverse processes are positioned more dorsally and they do not take part in the formation of the high neural canal, and the postzygapophyses are not situated above the transverse processes (Rieppel et al. 1999). The high neural spines and relative position of postzygapophyses (especially on the best-preserved PAL 2019.171.1. and PAL 2019.172.1. specimens) are most similar to the $N$. mirabilis vertebrae; on the other hand, the neural canal is wider on the illustrated specimens (Rieppel and Wild 1996: Fig. 20). In the case of PAL 2019.175.1., the morphology of transverse processes, zygapophyses, zygosphene and zygantrum is very similar to PAL 2019.171.1. and PAL 2019.172.1. but its neural spine is much lower. Despite this difference, we suggest that this neural arch probably belonged to the same taxon but was positioned on a different part of the vertebral column (e.g. cervical or caudal region).

Nothosauridae Baur, 1889

Nothosauridae indet.

(Fig. 5-7)

Material: two small-sized fragmentary skulls PAL 2019.156.1., PAL 2019.181.1.; a small fragmentary mandible PAL 2019.153.1.

Description: PAL 2019.156.1. (Fig. 5) is a dorsoventrally flat, small-sized partial skull preserved in almost three dimensions and comprises of the posterior region of the braincase and the parietal skull table, the posterior parts of the upper temporal arches and the almost complete basicranium. The total width of the cranium measured across the quadrates is $55 \mathrm{~mm}$, while the thickness is $15 \mathrm{~mm}$ measured between the pterygoids and the parietal. The squamosals form the posterior part of the upper temporal arches, and ventrally projecting ridges overhang from their ventral side. The suture of parietal and squamosals are visible by the posterior end of the temporal fenestrae. The unpaired (fused) parietal is posteriorly strongly constricted: it is only $2 \mathrm{~mm}$ thick by the narrowest point but does not form a sagittal crest. Due to the incompleteness of the skull, the dimension and exact position of the parietal foramen is unknown; however, it is separated from the posterior end of the parietal with a short distance. Anteriorly to this narrowest point of the constricted parietal, an anteriorly widening shallow dorsal depression is located, which indicates the close position of the parietal foramen. The anterior opening of the cranioquadrate passage is situated posterolaterally to the temporal openings on both sides. The passage is bordered ventrally by the pterygoid and roofed over by the squamosal. The posterior opening of the passage is present on the left side of the skull, while the squamosal is broken on the right side of this region. Ventrally, the basicranium is bordered by the pterygoids, which are posterolaterally diverging to the quadrates, which are almost on the same level as the basiocciptal. Both quadrates are preserved, but the right one is damaged. They are broad and flat elements; nevertheless, the effects of compression cannot be excluded. Ventrally, the pterygoids are fused with a strong interdigitating suture and ventromedial flanges are visible on the backward extending quadrate rami. The right pterygoid is more complete, while the left is laterally broken. The region around the foramen magnum is poorly preserved; the ventral (domed) part of the supraoccipital is incomplete. The more or less horizontally exposed supraoccipital carries a 1-mm-thick sagittal crest. An occipital crest is present dorsally to the supraoccipital; this crest being on average $2 \mathrm{~mm}$ high and $1 \mathrm{~mm}$ thick. The suture of the supraoccipital and parietal is not recognisable due to either the poor preservation or the complete ossification of the specimen. The exoccipital and opisthotic cannot be separated; however, the jugular foramen and paracondylar interstice (a term 

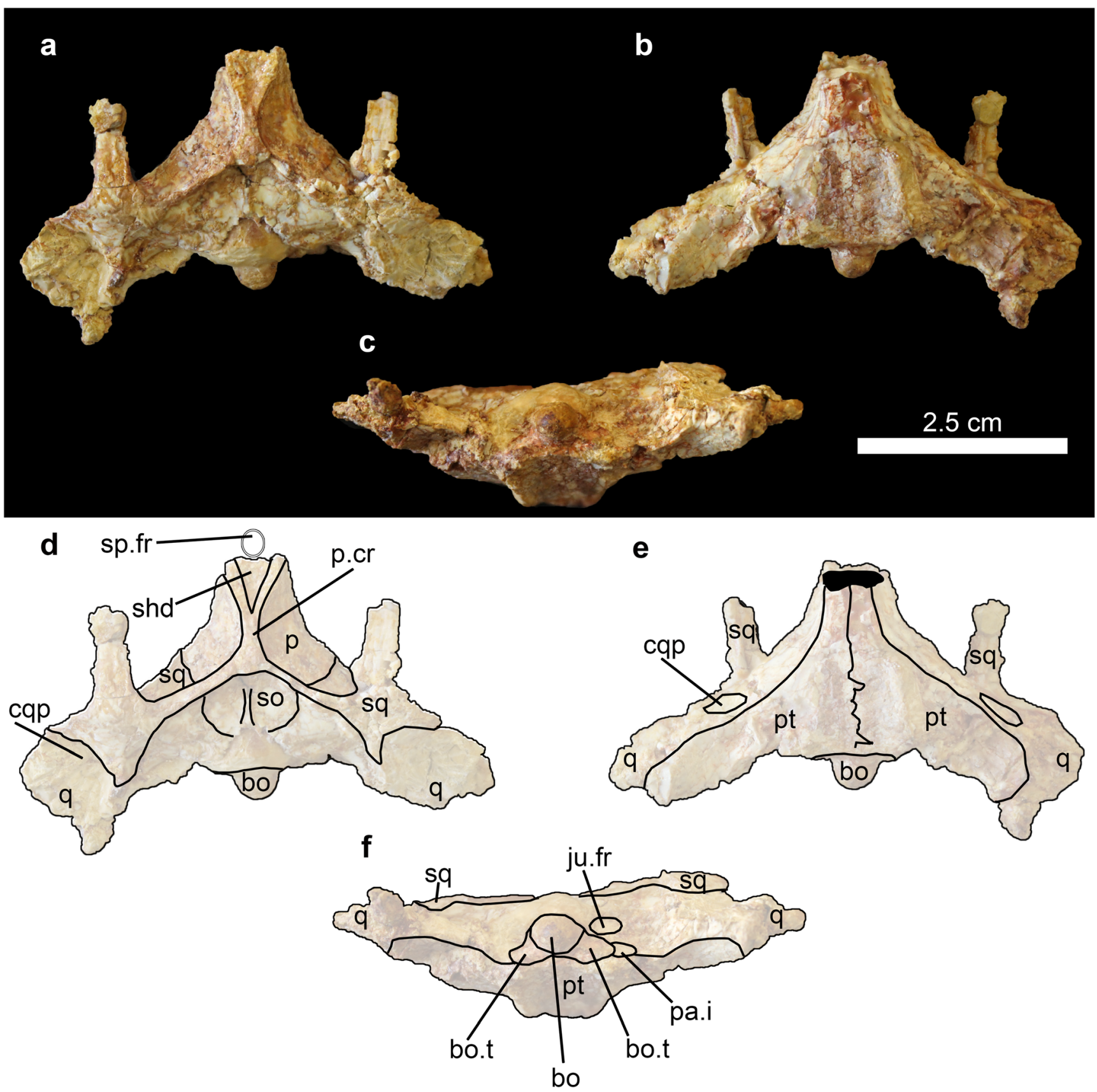

Fig. 5 Nothosauridae indet. skull fragment (PAL 2019.156.1.) from the Middle Triassic 'Construction site' of Villány, southern Hungary. a In dorsal, b in ventral, c in posterior view. d-f In dorsal, ventral and posterior view with details. Visible sutures are marked with solid lines. Anatomical abbreviations: bo basioccipital, bo.t basioccipital tuber, cqp

cranioquadrate passage, $j u . f r$ jugular foramen, $p$ parietal, $p a . i$ paracondylar interstice, $p . c r$ parietal constriction, $p t$ pterygoid, $q$ quadrate, shd shallow depression on parietal, so supraoccipital, $s p$. fr suggested position of parietal foramen, $s q$ squamosal

proposed in Voeten et al. 2018) are visible laterally to the basioccipital. The occipital condyle $(5 \mathrm{~mm}$ wide horizontally and $4 \mathrm{~mm}$ tall vertically) is built of only the basioccipital. Laterally to the condyle, two basioccipital tubera are present and the size of them is slightly smaller, but almost reaches the size of the basioccipital (each of them is $4 \mathrm{~mm}$ horizontally and $4 \mathrm{~mm}$ vertically). The sutures between the exoccipital, supraoccipital and opisthotic moreover between pterygoid, opisthotic and exoccipital are not clear.

PAL 2019.181.1. (Fig. 6) is a fragmentary, dorsoventrally compressed skull, comprised of a small remained part of the preorbital region, the parts around the right orbit, the postorbital region with the left temporal arch, braincase and basicranium. The skull is highly dolomitised anteriorly, 
Fig. 6 Nothosauridae indet. skull fragment (PAL 2019.181.1.) from the Middle Triassic 'Construction site' of Villány, southern

Hungary. a In dorsal view, b in right lateral view, $\mathbf{c}$ in dorsal view with details. Visible sutures are marked with solid lines, while interpreted sutures are marked with dashed lines. Anatomical abbreviations: bo basioccipital, $f$ frontal, $m$ maxilla, $m t$ maxillary teeth, $n$ nasal, $o$ orbit, $p$ parietal, p.cr parietal constriction, $p$.fr parietal foramen, $p o$ postorbital, $p o f$ postfrontal, $q$ quadrate, so supraoccipital, $s q$ squamosal

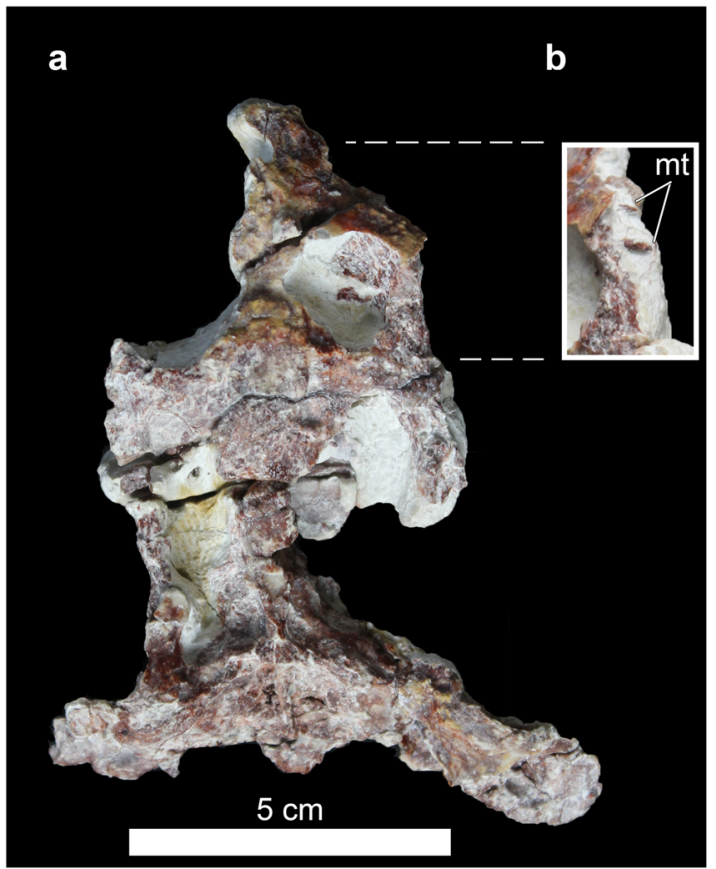

especially around the orbits, where the exact boundary between the bone and enclosing rock is not obvious. Whilst the real expansion of the orbits is not known, however, the upper temporal fossa definitely seems larger. The largest width of the skull is $86 \mathrm{~mm}$, measured across the compressed quadrates, while the largest length between the most anterior part and the occipital condyle is $120 \mathrm{~mm}$. The width of the skull, by the level of the most anterior points of the temporal fenestrae, is $50 \mathrm{~mm}$. The skull is distinctly flat; its thickness is $15 \mathrm{~mm}$ measured between the parietal and the pterygoids. The left temporal arch is preserved in better condition: the anteroposterior elongation of the left fenestra is $40 \mathrm{~mm}$, while its largest width is $12 \mathrm{~mm}$. The preserved right nasal is broad. Posteriorly to this nasal, the connection of the frontal and prefrontal is not visible. The unpaired frontal starts to widen behind the orbits. The postfrontal contacts the parietal posteriorly, unlike the postorbital which is not extended backward in medial direction. The suture of parietal and frontal is not visible. Due to the poor preservation of the specimen, the connection of postorbital with the jugal and maxilla, moreover the anterior sutures of squamosals, is not clear. Two small (3 and $4 \mathrm{~mm}$ long) pointed teeth with longitudinal striations are preserved in the right, fragmentary maxilla at the level of the orbits. The parietal is fused (unpaired). The parietal foramen is $6 \mathrm{~mm}$ long (anteroposteriorly) and $3.5 \mathrm{~mm}$ wide. It is separated from the posterior end of the parietal skull table with a 10$\mathrm{mm}$ distance. The parietal is strongly constricted behind the parietal foramen (by the narrowest point, it is only $3 \mathrm{~mm}$ wide), but it does not form a sagittal crest. The supraoccipital exposed more or less horizontally at the end of the parietal. The thickness of occipital crest, which is situated anteriorly to the supraoccipital, is $2 \mathrm{~mm}$, while it is $1 \mathrm{~mm}$ high. The openings of cranioquadrate passages are present posterolaterally to the temporal openings on both sides. The passage is bordered by the pterygoid ventrally and roofed over by the squamosal. Ventrally, the basicranium is bordered by the pterygoids, which are diverging posterolaterally to the quadrates. They are broad and flat elements, but especially the right quadrate is compressed. Ventrally, the pterygoids seem to be fused; however, the suture is not visible (probably due to the poor preservation). Ventromedial flanges are present on the backward extending quadrate rami. The suture of the supraoccipital and parietal is not recognisable, because of the preservation or the complete ossification. The supraoccipital carries a 1-mm-thick sagittal crest. The sutures of the exoccipital, supraoccipital and opisthotic moreover between the pterygoid, opisthotic and exoccipital are not clear. The occipital condyle is $6 \mathrm{~mm}$ high and $9 \mathrm{~mm}$ wide; however, the size and position of basioccipital tubera cannot be seen. The poor preservation around the occipital condyle and foramen magnum did not allow us to describe the basicranium in detail.

PAL 2019.153.1. (Fig. 7) is a fragmentary mandible with preserved in situ teeth. The mandible is exposed only dorsally, and the left side of its symphysis is covered by extraneous bone fragments. The left ramus is almost complete $(155 \mathrm{~mm}$ long, measured between the anteriormost point of the symphysis and the posterior end of the retroarticular process). Posteriorly, the long retroarticular process is compressed, but the articular is preserved. The right ramus is broken. The anterior part of the dentaries is fused in a lateromedially slightly wider than anteroposteriorly long, spoon-shaped symphysis. The length of the spoon-shaped mandibular symphysis is 


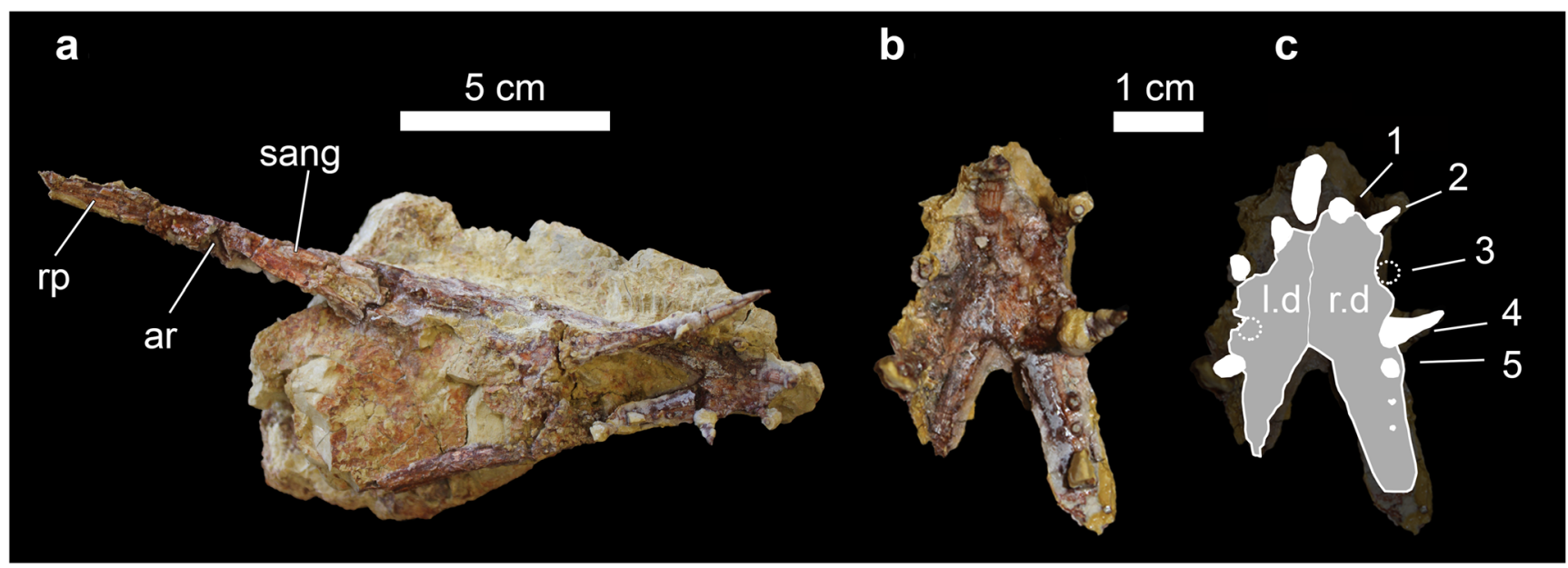

Fig. 7 Nothosauridae indet. mandible (PAL 2019.153.1.) from the Middle Triassic 'Construction site' of Villány, southern Hungary. a In dorsal view, b mandibular symphysis in dorsal view, $\mathbf{c}$ mandibular symphysis with details (large symphyseal teeth are numbered in the right dentary, missing teeth are drawn with dotted line). Anatomical abbreviations: ar articular, $l . d$ left dentary, $r . d$ right dentary, $r p$ retroarticular process, sang surangular

fossa, which is distinctly larger than the orbit, and the fused parietal suggest their sauropterygian origin. Among them, the highly compressed temporal region is a characteristic of Nothosauria; however, the fused frontals and constricted parietal differ from the skull of Germanosaurus Nopcsa, 1928. Moreover, based on the laterally extending basioccipital tubera, combined with the supraoccipital which is exposed rather horizontally at the posterior end of the parietal skull table, and because the mandibular articulations are almost on the same level as the occipital condyle, we suggest they belong to Nothosauridae (Rieppel 1998). The braincase and basicranium morphology is not diagnostic without the anterior region of the skull (Rieppel 2000); thus, the anatomy of PAL 2019.156.1. and PAL 2019.181.1. is not useful itself for the accurate determination, because the basicranium and braincase of Nothosaurus or Lariosaurus Curioni, 1847 genera are very similar (Rieppel 1994b). The ossified braincase and the deeply interdigitating suture of pterygoids suggest that both skulls mentioned here belonged to fully grown animals, but since the ontogenetic stages of many eosauropterygian is unknown, this feature is always a matter of question. Nevertheless, it must be noted that several nothosaurid species are known with a similarly small adult skull size (Rieppel and Wild 1996; Rieppel 2000).

The relative position of the parietal foramen is situated somewhat more anteriorly than the posterior end of the parietal skull table; moreover, the highly constricted parietalwhich does not form a sagittal crest-is similar to that of Nothosaurus jagisteus Rieppel, 2001, N. marchicus, $N$. rostellatus Shang, 2006, Lariosaurus xingyiensis Li, Liu and Rieppel, 2002 and $L$. valceresii Tintori and Renesto, 1990 (Tintori and Renesto 1990; Rieppel and Wild 1996; Rieppel 2001; Li et al. 2002; Rieppel et al. 2003; Shang 2006). This kind of parietal structure is unlike that tipically observed in 
crania of middle- or large-sized Nothosaurus species, such as $N$. mirabilis or $N$. giganteus Münster, 1834. Another interesting feature of the PAL 2019.156.1. is the large size of basioccipital tubera, which are almost as large as the basioccipital. Based on the available information, both $N$. marchicus and $N$. jagisteus can be described with proportionally smaller tubera; however, these features are not known in the case of every nothosaurid species (Rieppel et al. 2003). The large basioccipital tubera are mentioned as an important character of $N$. edingerae Schultze, 1970 (Rieppel and Wild 1994), but this animal had a distinct sagittal crest behind the parietal foramen (a feature, which is missing from the skulls described here). In comparison with the more complete skull, the cranium of $N$. jagisteus is different because the postorbital extends backward medially and meets the parietal posteriorly, and the nasals are slender, elongated elements, and also, the temporal fenestrae are somewhat more elongated (Rieppel 2001). Lariosaurus xingyiensis is also different with its proportionally smaller, triangular-like postfrontals and connected postorbital and parietal (Rieppel et al. 2003; Lin et al. 2017). $N$. rostellatus differs again with its connected postorbital and parietal, and the parietal posteriorly seems less constricted (Shang 2006). The parietal-postorbital-postfrontal arrangement of Lariosaurus valceresii is similar to the skull (PAL 2019.181.1.) from Villány; however, the nasals of this species are trapezoidal and on the skull (PAL 2019.181.1.) there is no sign of such a broad prefrontal visible on $L$. valceresii (Tintori and Renesto 1990).

The small overall size and posteriorly constricted parietal, moreover the distance between the posteriorly displaced parietal foramen and the posterior margin of parietal skull table, resemble $N$. marchicus, which species is also known by its broad and 'leaf-shaped' nasals (Rieppel and Wild 1996; Rieppel 2000). In fact, among the $N$. marchicus specimens, the parietal-postorbital-postfrontal arrangement visible on PAL 2019.181.1. is present on the skulls described as N. procerus (see Rieppel and Wild 1996: Fig. 34). According to Schultze (1970), N. procerus and N. marchicus were separate species, and one of the main characteristics that led to this conclusion was the relation of postfrontal and postorbital with the margin of upper temporal fenestra. In the case of $N$. procerus, the participation of postfrontal in the laterally descending flanges of the medial margin of upper temporal fenestra is significant, while the postorbital is not extended medially into the flanges. Following the revision of Rieppel and Wild (1996), $N$. procerus is now believed to be the synonym of $N$. marchicus, and according to these authors, the characters that differentiated the two species show a continuous transition among the $N$. marchicus specimens.

Based on its laterally projecting ridge on the surangular, distinct long retroarticular process, the lack of distinct coronoid process, combined with the spoon-shaped mandibular symphysis with low length/width ratio, moreover the strongly procumbent anterior teeth in the dentaries (5 in each), the partial mandible PAL 2019.153.1. is assigned to Nothosauridae indet. (Rieppel 1998; Liu et al. 2014). The low maximal length/width ratio (L/W: 0.77) of the symphysis suggests a plesiomorphic skull condition (Rieppel 2000). The ratios of the symphysis, moreover the number and position of the large anterior procumbent fang-like teeth (five large teeth in each dentary, the fifth teeth is behind the level of the symphysis, the fourth and fifth teeth are only separated by a thin bone septum), correspond to the previously described (Ösi et al. 2013: Fig. 6) Nothosaurus sp. mandible (Ver 2013.1.) from the Villány locality. However, that previously described specimen is much larger and their maximal length/with ratio is 0.86 (Ösi et al. 2013). Among nothosaurs, $N$. giganteus (L/W: 1-1.03), N. marchicus (L/W: 0.7-1) and $N$. zhangi Liu et al., 2014 (L/W: 0.64) was described with similarly low length-towidth ratios (Rieppel and Wild 1996; Rieppel 2000; Liu et al. 2014). Unfortunately, the material referred to as $N$. zhangi exhibits only the ventral side of the symphysis (Liu et al. 2014); thus, further information about the position of the teeth is not available. The average size of the $N$. marchicus mandibles is quite similar to the PAL 2019.153.1. specimen, but in the case of $N$. marchicus all of the teeth are separated by the same distance in the symphysis (Rieppel and Wild 1996). The position of the teeth is similar to $N$. giganteus among the nothosaurs with plesiomorphic mandible morphology (Rieppel and Wild 1996). However, because the PAL 2019.153.1. specimen is too fragmentary and character changes through the ontogenetic stages of nothosaurs are not known, more precise taxonomic identification is not possible at present. An enigmatic eosauropterygian mandible was described from the Lower Muschelkalk (Vossenveld Formation) of Winterswijk, the Netherlands, with a similar number and arrangement of teeth, and similar angle of rami (but with a higher symphyseal ratio) (Voeten et al. 2015). Based only on its anatomy, the PAL 2019.153.1. specimen could represent a juvenile $N$. giganteus, or a species with previously unknown mandible remains, but its affinity to $N$. marchicus is also noteworthy.

Simosauria Rieppel, 2000

Simosauridae Huene, 1948

Simosauridae indet.

(Fig. 8)

Material: vertebra PAL 2019.180.1.; three isolated dorsal neural arch Ver 2013.5., PAL 2019.178.1., PAL 2019.179.1. Description: Isolated dorsal neural arches (Fig. 8) (Ver 2013.5., PAL 2019.178.1., PAL 2019.179.1.) with moderately high, dorsoventrally grooved neural spines and massive transverse processes are referred to here as Simosauridae. Besides the pre- and postzygapophyses, additional infrapreand infrapostzygapophyses can be observed on them. The 


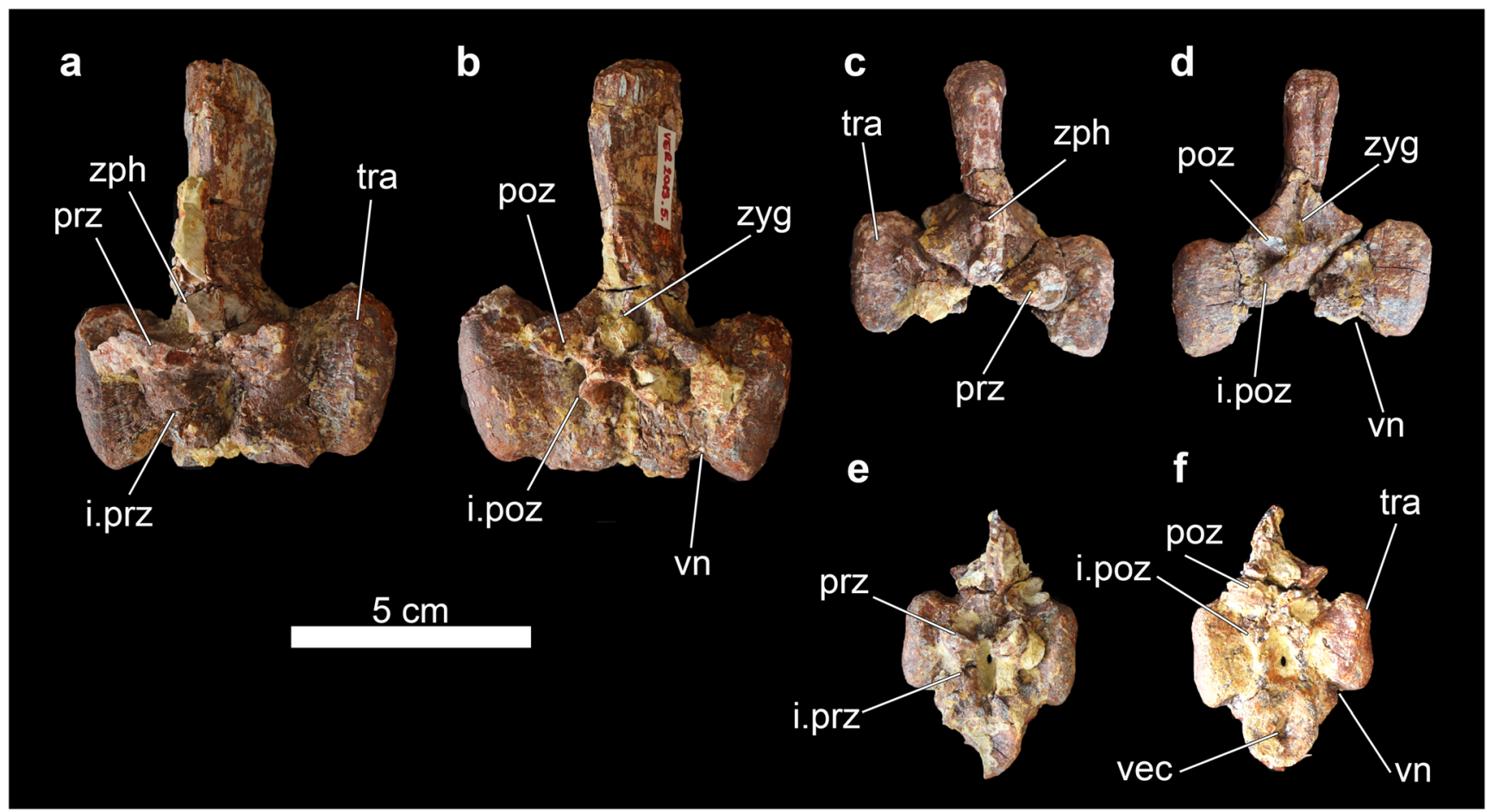

Fig. 8 Simosauridae indet. vertebrae from the Middle Triassic 'Construction site' of Villány, southern Hungary. a-b Ver 2013.5. isolated dorsal neural arch in anterior and posterior view. c-d PAL 2019.179.1. isolated dorsal neural arch in anterior and posterior view. e-f PAL 2019.180.1. vertebra in anteror and posterior view.

height of the neural spines is between 44 and $66 \mathrm{~mm}$, while the width of transverse processes ranges from 50 to $66 \mathrm{~mm}$. The top of the neural spine tilts into cranial direction, and thin zygosphene and zygantrum articulations are present; however, they are mostly fragmentary. Pre- and postzygapophyses are not swollen, the prezygapophyses are wedge-like and the neural canal is high and rectangular in cross-section. Ventrally to the transverse processes, a shallow ventral notch can be observed. Ver 2013.5. is a well-preserved large isolated dorsal neural arch with a 66-mm-tall neural spine and with the 66$\mathrm{mm}$ largest width of the transverse processes. PAL 2019.180.1. (Fig. 8(e-f)) is a vertebra with 26-mm-tall neural arch and 38-mm-wide transverse processes. The infrapre- and infrapostzygapophyses are reduced compared to the other mentioned neural arches. The neural arch is fused with the amphicoelus centrum along the neurocentral suture.

Discussion: On the basis of the presence of zygosphenezygantrum, moreover, infrapre- and infrapostzygapophysis articulations, the vertebra and neural arches assigned here to Simosauridae (Rieppel 1998; de Miguel Chaves et al. 2019). The vertebrae of the pistosaurid Bobosaurus forujuliensis were also described with additional infraprezygapophysesinfrapostzygapophyses; however, with reversed anteroposterior polarity (Dalla Vecchia 2006), moreover Bobosaurus exhibits highly elongated neural spines. Within Simosauridae, the lack of zygapophyseal pachyostosis, the presence of ventral notch
Anatomical abbreviations: i.poz infrapostzygapophysis, i.prz infraprezygapophysis, poz postzygapophysis, $p r z$ prezygapophysis, tra transverse process, vec vertebral centra, $v n$ ventral notch, $z p h$ zygosphene, zyg zygantrum

on transverse processes, furthermore, because the dorsal neural arches are as large as high, make them most similar to the vertebrae of Simosaurus gaillardoti Meyer, 1842 (de Miguel Chaves et al. 2019).

Nothosauroidea Baur, 1889

Nothosauroidea indet.

(Fig. 9)

Material: two isolated ilium PAL 2019.157.1., PAL 2019.158.1.

Description: Two isolated ilia (Fig. 9) are discussed here: PAL 2019.157.1. is $41 \mathrm{~mm}$ long, while PAL 2019.158.1. is larger, and more elongated, but fragmentary $59 \mathrm{~mm}$ long ilium. They are constricted in the middle, between the reduced iliac blade and the ventrally expanded deeply concave acetabulum. The iliac blade is not projecting beyond the posterior margin of acetabular portion. Medially, the bone surface is strongly striated.

Discussion: Following the analysis of Rieppel (1998) and Liu et al. (2014), the reduced iliac blade which is not projecting beyond the posterior margin of acetabular portion of the ilium is a morphology, typical of Simosaurus and Nothosaurus genera. In a comparison, within Nothosauroidea, the ilia of Lariosaurus are different; they are reduced to a simple dorsal stub (Rieppel 1998). The articular facets of these ilia seem to 


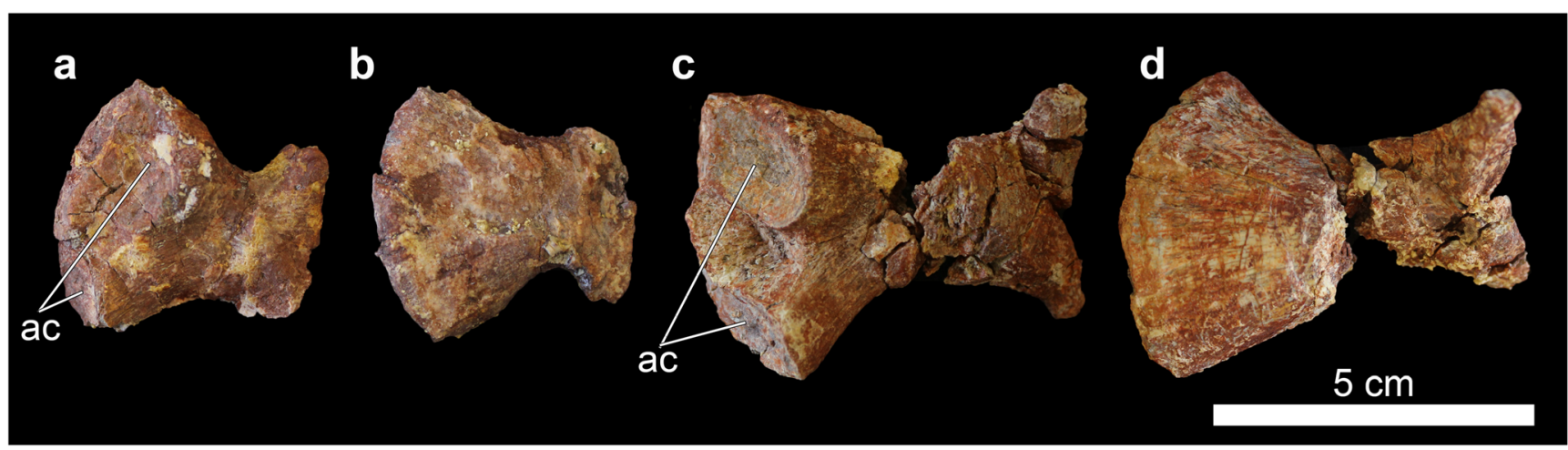

Fig. 9 Nothosauroidea indet. ilia from the Middle Triassic 'Construction site' of Villány, southern Hungary. a-b PAL 2019.157.1. in lateral and medial view. c-d PAL 2019.158.1. in lateral and medial view. Anatomical abbreviations: $a c$ acetabulum

be not subdivided, which makes them more similar to those of Nothosaurus (Rieppel 1994a). These remains are also unlike the ilia belonging to Pistosaurus Meyer, 1839, which has a well-developed iliac blade (Rieppel 1998). This character also differs in the case of Placodontia and Corosaurus Case, 1936; because the reduced dorsal process of those is more expanded, they are projecting beyond the level of the posterior margin of the acetabular portion (Rieppel 1998, 2000).

Eosauropterygia Rieppel, 1994a

Eosauropterygia indet.

(Fig. 10-15)

Material: a skull fragment (temporal arch) PAL 2019.170.1.; a large-sized fragmentary right mandibular ramus PAL 2019.155.1.; small mandibular ramus fragments Pal
2019.151.1., Pal 2019 152.1., PAL 2019.154.1.; isolated scapulae PAL 2019.162.1., PAL 2019.163.1., PAL 2019.164.1., PAL 2019.165.1.; isolated coracoids PAL 2019.166.1., PAL 2019.167.1., PAL 2019.168.1., PAL 2019.169.1.; humeri PAL 2019.199.1., PAL 2019.200.1., PAL 2019.201.1., PAL 2019.202.1., PAL 2019.203.1., PAL 2019.204.1.; isolated ischia PAL 2019.159.1., PAL 2019.160.1., PAL 2019.161.1.

Description: PAL 2019.170.1. is a skull fragment (Fig. 10) possibly representing the right temporal arch, parts of the postorbital region and the projections of squamosal around the cranio-quadrate passage. The fragment is $109 \mathrm{~mm}$ long anteroposteriorly and the width of the squamosal in the arch is between 9 and $10 \mathrm{~mm}$. The temporal arch is triangular in crosssection. The possible cranioquadrate passage is $9 \mathrm{~mm}$ wide. Anteromedially, the squamosal shows a 36-mm-long groove, which probably represents the suture of the postorbital.
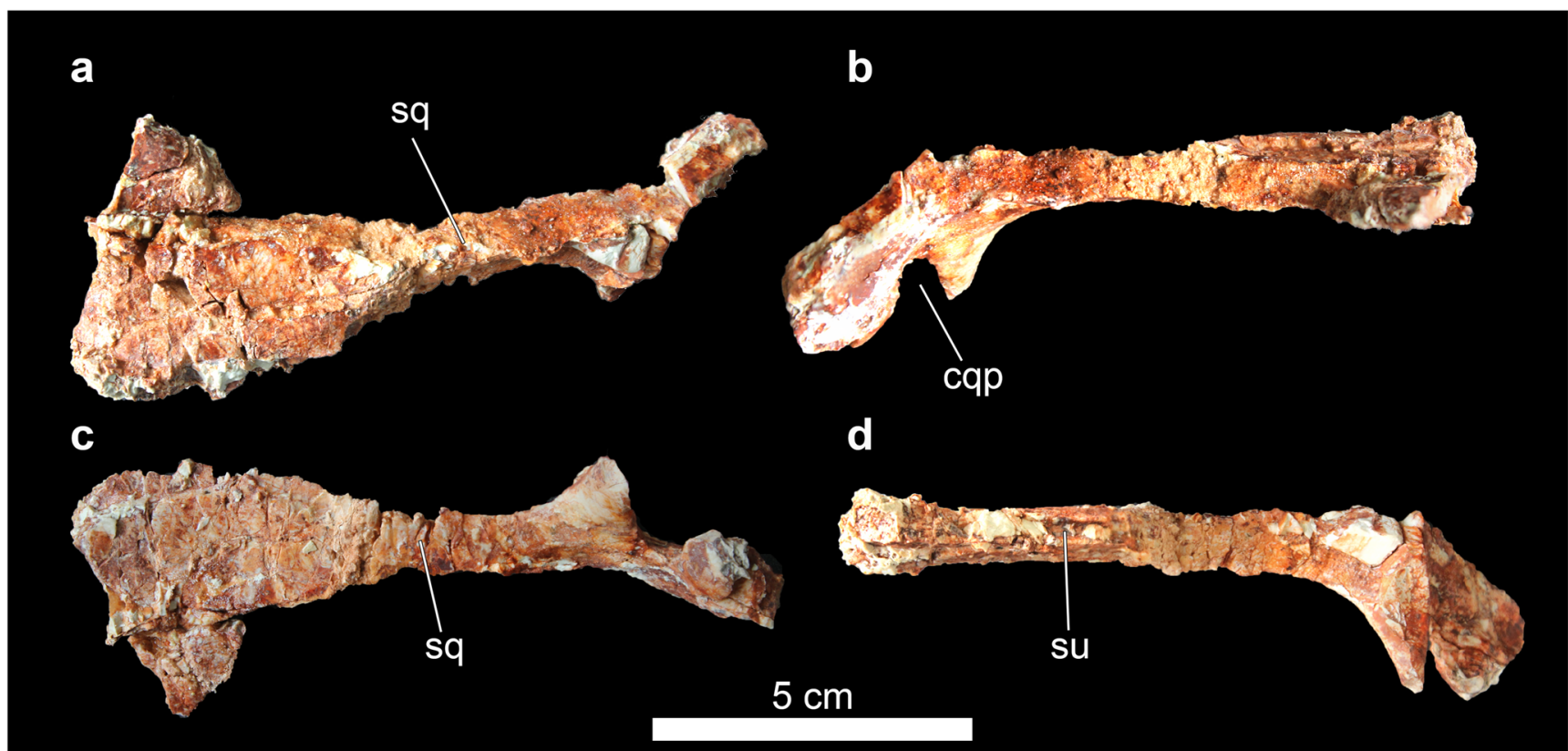

C

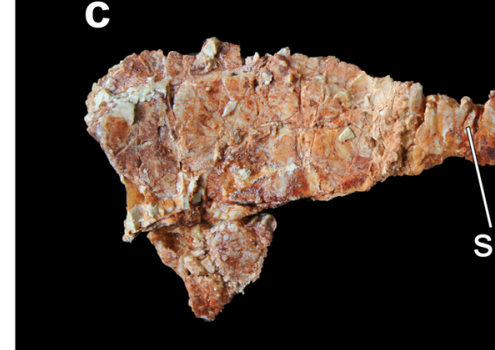

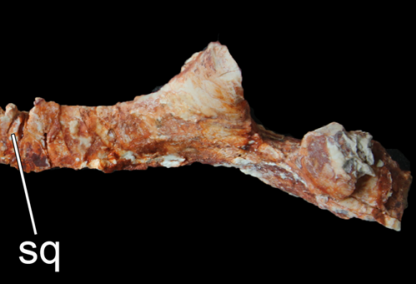

Fig. 10 Eosauropterygia indet. skull fragment (PAL 2019.170.1.) from the Middle Triassic ‘Construction site' of Villány, southern Hungary. a In dorsal view, $\mathbf{b}$ in lateral, $\mathbf{c}$ in ventral, $\mathbf{d}$ in medial view. Anatomical abbreviations: $c q p$ cranioquadrate passage, $s u$ suture, $s q$ squamosal 


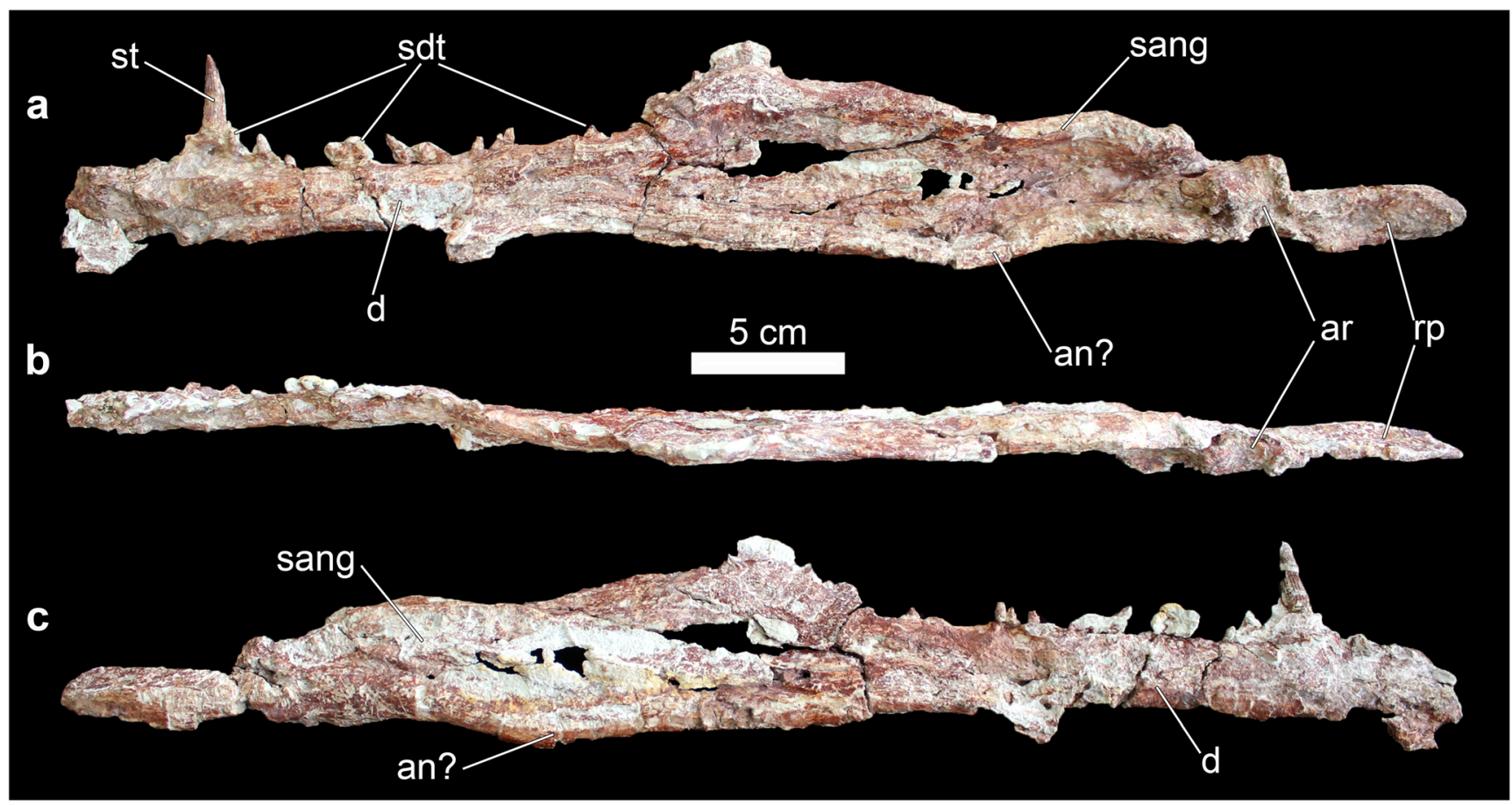

Fig. 11 Eosauropterygia indet. mandibular ramus (PAL 2019.155.1.) from the Middle Triassic 'Construction site' of Villány, southern Hungary. a In medial view, b in dorsal view, c in lateral view.

PAL 2019.155.1. (Fig. 11) is a large, 490-mm-long, fragmentary right mandibular ramus with preserved in situ teeth. The mandible is damaged and because of its poor preservation, the diagnostic features, such as the ratio of its mandibular symphysis, and number and position of large anteriorly positioned fangs, cannot be noticed. However, the only remained $31 \mathrm{~mm}$ long, vertically striated fang-like tooth is the most posteriorly situated one in the symphysis because it is immediately followed by numerous small (between 5 and $15 \mathrm{~mm}$ high) pointed teeth in the dentary. Fifteen small teeth are visible in the dentary, and their preservation is very poor, sometimes dolomitised. It is impossible to reconstruct the original morphology of the symphysis region, because anteriorly the bone is crushed and alveoli are not recogniseable. However, the shape of the ramus, and the position of the last fang, which is situated medially close to the level of the dentary, does not suggest a wide lateral expansion for the mandibular symphysis. The surangular holds a laterally projecting ridge, and the ramus lacks a distinct coronid process. The ramus is $65 \mathrm{~mm}$ high by its middle region; however, it was mediolaterally crushed and highly dolomitised. The distance between the last tooth of the symphysis and the posteriormost point of the long retroarticular process is $430 \mathrm{~mm}$. The distance between the posteriormost point of the articular surface and the posteriormost point of the retroarticular process is $68 \mathrm{~mm}$.

Pal 2019.152.1. (Fig. 12(a-d)) is an $84 \mathrm{~mm}$ long, posterior fragment of a left mandibular ramus. The distinct retroarticular process distally and the articular laterally are broken.
Anatomical abbreviations: an angular, ar articular, $d$ dentary, $r p$ retroarticular process, sang surangular, st symphyseal tooth, sdt series of small dentary teeth

Surangular, prearticular and angular are present, and possibly the chorda tympani foramen is visible posteriorly to the articular. The splenial and dentary are both missing. The articular surface is roundish in a dorsal view, it is $22 \mathrm{~mm}$ long and $24 \mathrm{~mm}$ wide. Medially, the posterior part of the adductor fossa is visible, and the angular is situated below the mandibular joint. The surangular laterally forms a strongly projecting ridge.

Pal 2019.151.1. (Fig. 12(e-h)) is a 116-mm-long fragmentary right mandibular ramus. The long retroarticular process is intact, but the articular surface is slightly broken. However, the shape of the latter is saddle-like and its appearance suggests a mediolaterally wider $(18 \mathrm{~mm})$ than anteroposteriorly long $(13 \mathrm{~mm})$ articular surface. The surangular and prearticular are present but the dentary is broken. The surangular defines laterally the ramus and forms a lateral ridge. The angular is also damaged and incomplete, but probably it was situated under the mandibular joint. There is no sign of a distinct coronoid process. The distance between the posteriormost point of the retroarticular process and the posteriormost point of the articular surface is $30 \mathrm{~mm}$.

PAL 2019.154.1. (Fig. 13) is a 120-mm-long fragmentary and mediolaterally slightly compressed, posterodorsally curved left mandibular ramus. The articular, angular, prearticular and surangular are present, but the splenial, dentary and probably the coronoid bone are missing. The retroarticular process is short and stout, with a foramen on its dorsal surface probably for the innervation of chorda 


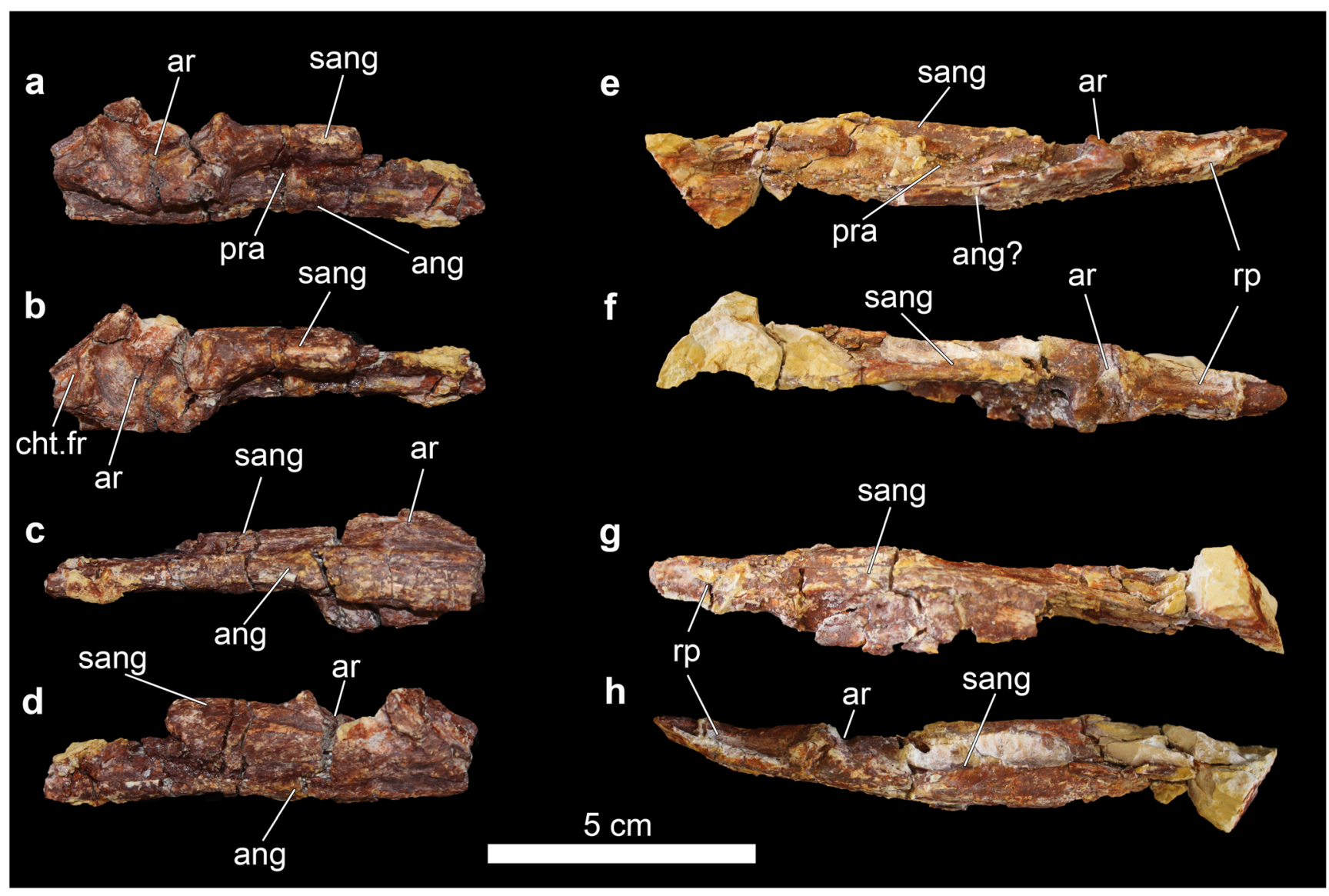

Fig. 12 Eosauropterygia indet. mandible fragments from the Middle Triassic 'Construction site' of Villány, southern Hungary. a-d Pal 2019.152.1. in medial, dorsal, ventral and left lateral view. e-h Pal

2019.151.1. in medial, dorsal, ventral and right lateral view. Anatomical abbreviations: ang angular, ar articular, cht.fr chorda tympani foramen, pra prearticular, $r p$ retroarticular process, sang surangular

tympani nerve. Both the lateral and medial surface of retroarticular process holds a trough, probably for the insertion of muscles and fibres. The articular surface is dorsally opened and saddle-shaped. The measurable width of it is $18 \mathrm{~mm}$, while it is anteroposteriorly $31 \mathrm{~mm}$ long. The distance between the posteriormost point of the retroarticular process and the posteriormost point of the articular is $15 \mathrm{~mm}$. The presence of a coronoid is uncertain due to the

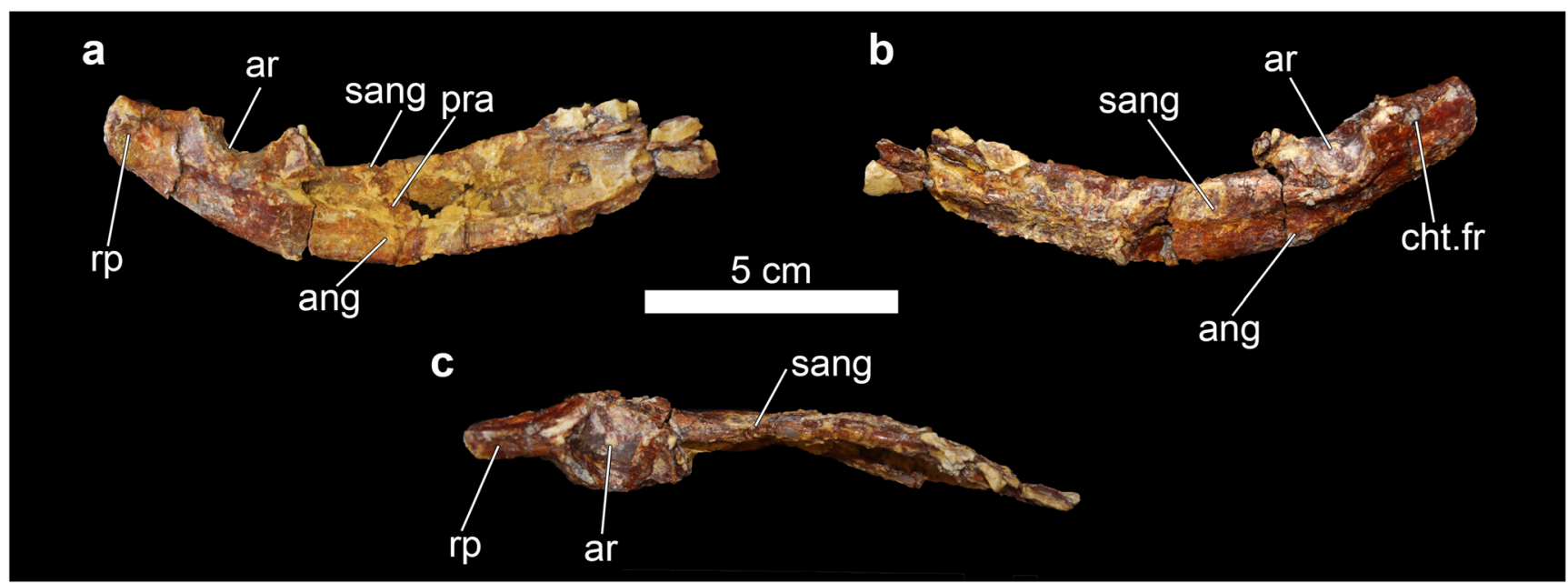

Fig. 13 Eosauropterygia indet. mandible fragment (PAL 2019.154.1.) from the Middle Triassic 'Construction site' of Villány, southern Hungary. a In medial view, $\mathbf{b}$ in lateral view, $\mathbf{c}$ in dorsal view.
Anatomical abbreviations: ang angular, ar articular, cht.fr chorda tympani foramen, pra prearticular, $r p$ retroarticular process, sang surangular 
breakage; however, there is no sign of such a distinct coronoid process. Laterally, the surangular covers the ramus and forms a laterally projecting ridge, while ventrally the angular borders the bone. The adductor fossa is visible medially, with the prearticular situated inside. On the medial side, ventrally to the prearticular, the angular forms a prominent ridge, and the surangular borders the prearticular dorsally.

The isolated scapulae (PAL 2019.162.1., PAL 2019.163.1., PAL 2019.164.1., PAL 2019.165.1.) display the typical eosauropterygian scapular morphology (Fig. 14(a-b)). The wide ventrally expanded (26-36 mm long) glenoidal part is separated by a distinct neck from a narrow posterodorsally oriented (30$46 \mathrm{~mm}$ long) reduced scapular blade. If intact, the blade tapers to a constricted but blunt tip. The projection of coracoid foramen is not recognisable on the specimens from Villány.

Among girdle elements, four coracoids (PAL 2019.166.1., PAL 2019.167.1., PAL 2019.168.1., PAL 2019.169.1.) represent a strongly waisted morphology (Fig. 14(c-d)). They are flat elements with anteriorly and posteriorly deeply concave margins, their mediolateral width changes between 106 and $126 \mathrm{~mm}$. They are expanded medially and laterally; moreover, their lateral margin forms the medial side of the coracoid foramen. The coracoids presented here are both damaged on their lateral side; thus, the position of this foramen is visible but its exact expansion and angle is not clear.

Isolated humeri (PAL 2019.199.1., PAL 2019.200.1., PAL 2019.201.1., PAL 2019.202.1., PAL 2019.203.1., PAL
2019.204.1.) with the following morphology assigned here to Eosauropterygia (Fig. 15). They are flat on their ventral side, and they have a robust proximal and a slightly widened distal epiphysis with weakly developed epicondyles. Their size ranges between 55 and $130 \mathrm{~mm}$. The diaphysis is not constricted and the cross-section of the midshaft is triangular, indicating the reduced musculus latissimus dorsi insertion (which is a ridge on the proximal dorsal side). They are slender bones with curved pre- and postaxial margins (the angle of flexion on their diaphysis is almost the same on both margins). Postaxially, they hold an entepicondylar foramen. In the case of well-preserved specimens, a shallow ectepicondylar groove is also visible. They have a bulbous proximal head and their deltopectoral crest (on the ventral side) is only slightly protruding in the case of larger specimens.

The isolated ischia (PAL 2019.159.1., PAL 2019.160.1., PAL 2019.161.1.) are also fragmentary remains (Fig. 14(ef)). Their size (measured between the constricted dorsal and the expanded ventral parts) ranges between 71 and $80 \mathrm{~mm}$. The bones are flat elements, the anterior and posterior margins are distinctly concave and the bone surface is striated. Given their fragmentary preservation, the symmetry or asymmetry of the margins is questionable.

Discussion: The possible size and elongation of the temporal fenestra, and the slender temporal arch structure in the case of PAL 2019.170.1. specimen differs from the skulls of placodonts, and most similar to the skull structure of Nothosauria, and also Corosaurus and Cymatosaurus

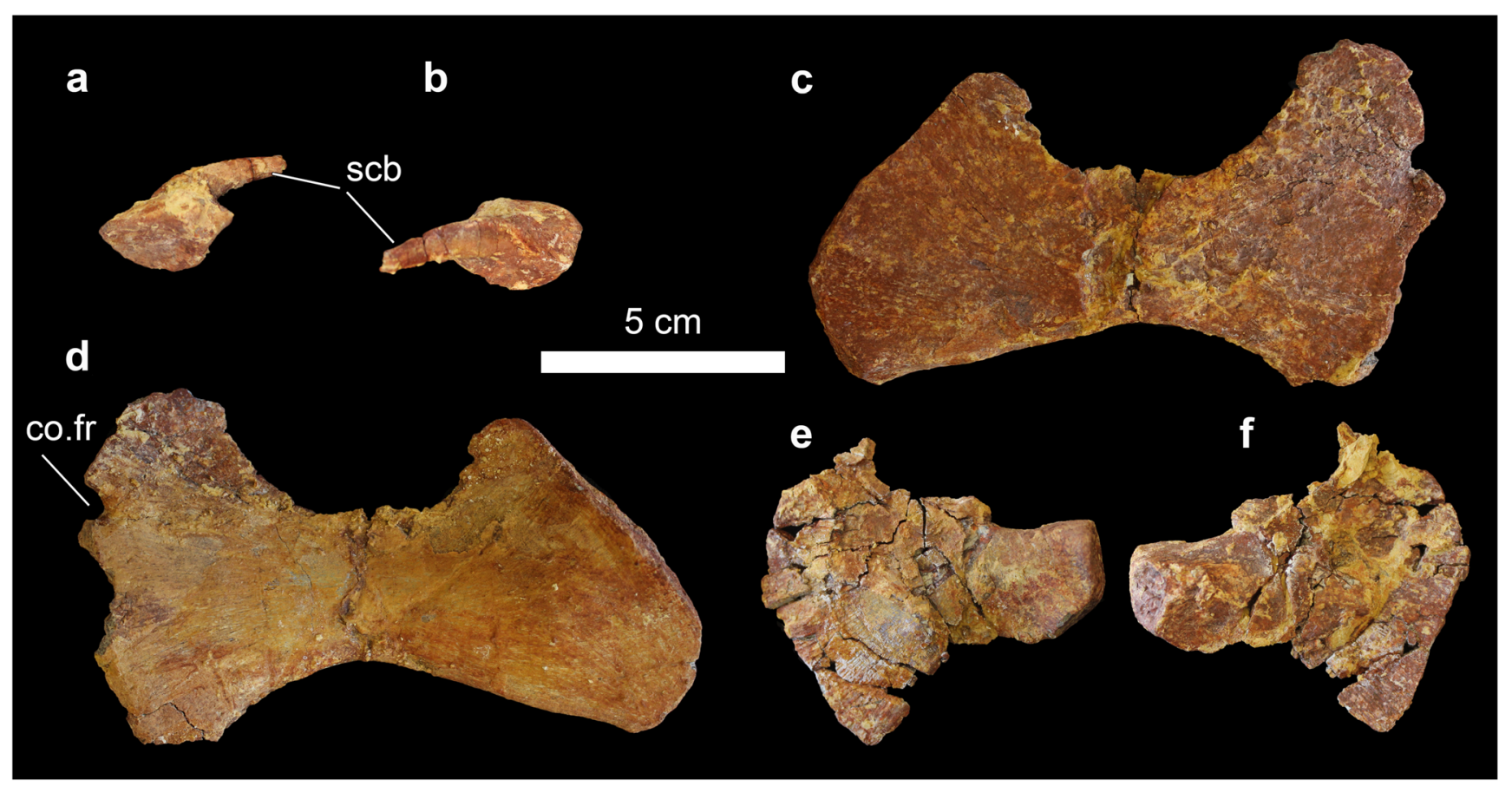

Fig. 14 Eosauropterygia indet. girdle elements from the Middle Triassic 'Construction site' of Villány, southern Hungary. a-b PAL 2019.164.1. scapula in medial and lateral view. c-d PAL 2019.166.1. coracoid in medial and lateral view. e-f PAL 2019.161.1. ischium. Anatomical abbreviations: $c o$.fr coracoid foramen, $s c b$ scapular blade 


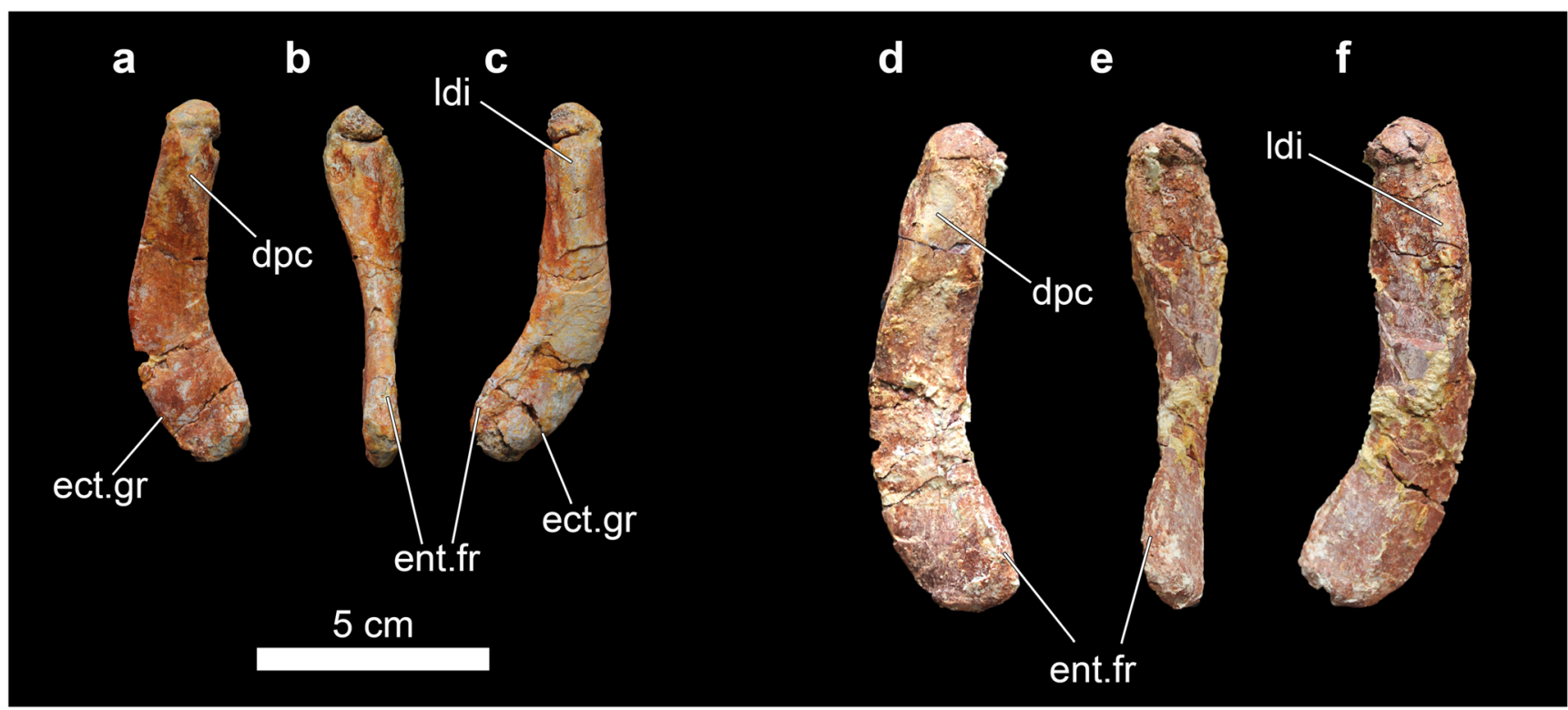

Fig. 15 Eosauropterygia indet. humeri from the Middle Triassic 'Construction site' of Villány, southern Hungary. a-c PAL 2019.201.1. in ventral, postaxial and dorsal view. d-f PAL 2019.202.1. in ventral,

Fritsch, 1894 (Rieppel 2000, 2002). The position of cranioquadrate passage is similar to that of nothosaurids, but the horizontal expansion of the bone in the postorbital area seems unlikely than in the case of nothosaurid skulls (but there is a chance that this region suffered significant torsion). Pistosaurus, Simosaurus and Germanosaurus exhibit a wider temporal arch structure (Sues 1987; Rieppel 2000, 2002; de Miguel Chaves et al. 2018b).

The large-sized (490 $\mathrm{mm}$ long) fragmentary right mandibular ramus PAL 2019.155.1. was longer with several centimetres, since the anterior part of the symphysis is broken. The laterally projecting ridge on surangular suggests its affinity to Eosauroperygia (Rieppel 1998); moreover, the relatively elongated retroarticular process differentiates it from the jaw of Simosaurus (Rieppel 1994a). Unfortunately, no lower jaw is known for Cymatosaurus and Pistosaurus; thus, detailed comparison with them is not possible (Rieppel 2002). However, the skull of Pistosaurus and Augustasaurus Sander, Rieppel and Bucher, 1997 is highly similar, and, as was suggested by Rieppel (2002), probably their mandible could have been alike. In the case of Augustasaurus, heterodonty is present, but the difference between the enlarged anterior (fang-like) and the following teeth behind them is less significant (Rieppel 2002) than what is present on the PAL 2019.155.1. mandible specimen (Rieppel 2000,2002). The size of the specimen and the presence of highly elongated procumbent teeth in the symphysis suggest its affinity to a larger nothosaur species like $N$. giganteus, $N$. zhangi or maybe N. mirabilis (Rieppel and Wild 1996; Rieppel 2000; Liu et al. 2014); however, its preservational condition does not allow us to state this for sure. The condylobasal skull length of the largest known skull referred to as postaxial and dorsal view. Anatomical abbreviations: $d p c$ deltopectoral crest, ect.gr ectepicondylar groove, ent.fr entepicondylar foramen, ldi latissimus dorsi insertion

$N$. giganteus is $750 \mathrm{~mm}$, while the largest known full mandible is $610 \mathrm{~mm}$ long (Rieppel and Wild 1996). The lower jaw of $N$. zhangi is measured $650 \mathrm{~mm}$ (Liu et al. 2014), whereas the largest described $N$. mirabilis skull was $460 \mathrm{~mm}$ long (Rieppel 2000). Without the intact characteristic symphysis area, the mandible cannot be described surely as neither $N$. mirabilis nor $N$. giganteus or $N$. zhangi. Its size could fit surely into the known sizes of the two larger species, but because the ontogenetic stages of nothosaurs are not known (Rieppel 2000), we cannot exclude that the mandible belonged to a larger $N$. mirabilis specimen. Moreover, the preserved part of the symphysis area does not suggest a wide lateral expansion, which could refer to $N$. giganteus or $N$. zhangi; in contrast, it is more similar to the elongated mandibular symphysis of $N$. mirabilis.

In the case of Pal 2019.151.1. and Pal 2019.152.1. mandible fragments, referred to here as Eosauropterygia, the laterally projecting shelf of the surangular is the main character what differentiates these remains from placodonts (Rieppel 1998). Unfortunately, they are not diagnostic without the mandibular symphysis region (Rieppel 1998). The broadened angular of $\mathrm{Pal}$ 2019.151.1. with distinct slender, long retroarticular process suggests its affinity to Nothosauridae (Rieppel 2000, 2002). These bones are straight and slender, which somewhat differs from the more curved mandible of Simosaurus (Rieppel 1994a), and the long retroarticular process of $\mathrm{Pal}$ 2019.151.1. is also different from the stout process of the latter genus. Unfortunately, a comparable three-dimensionally preserved Cymatosaurus mandible is not known (Rieppel 2000, 2002); however, both fragments described here differ from the mandible of Corosaurus, because the articular glenoid fossa on the Pal 2019.152.1. specimen is proportionally larger than those of the 
latter genus and the more complete Pal 2019.151.1. lacks the distinct coronoid process, which is characteristic for Corosaurus (Storrs 1991). The mandible of Augustasaurus (and the hypothetical reconstruction of the unknown jaw morphology of Pistosaurus based on Augustasaurus by Rieppel, 2002) is a more curved and dorsoventrally more elevated structure. The mandible fragments described here have differently shaped (roundish and more oval) articular glenoid fossae. The taxonomic importance of these features is not known; nevertheless, the mandible fragment Pal 2019.152.1. is very similar to those what Rieppel (1994a) tentatively described as N. mirabilis (Rieppel 1994a: Fig. 12).

Supported by the laterally strongly projecting ridge of its surangular, the PAL 2019.154.1. specimen belongs to Eosauropterygia, while the lack of a distinct coronoid process differentiates it from the mandible of placodonts and Corosaurus (Storrs 1991; Rieppel 1998). Due to its size, the specimen seems different than the smaller mandibles referred to as pachypleurosaurs (Rieppel 2000), but it is too fragmentary for a more precise determination. The stout retroarticular process of the robust mandible, with a deep trough on its lateral and medial surface for muscle and tendon attachment, is very similar to Simosaurus gaillardoti (Rieppel 1994a; Liu et al. 2014). Within Simosauridae, besides S. gaillardoti, the known mandible of Paludidraco multidentatus de Miguel Chaves, Ortega and Pérez-Garcia, 2018a exhibits a similar short retroarticular process, but the mandible of this species seems to be more slender, thinner.

The isolated scapulae, based on their separated glenoidal part and dorsal wing, which tapers to a blunt tip, are referred to here as Eosauropterygia (Rieppel 1998, 2000). In contrast, these girdle elements of placodontians are more simple, broad, plate-like bones (Rieppel 1995, 1998, 2000; Scheyer 2010).

The coracoids with strongly waisted contours presented here can be differentiated based on this character from the coracoids of Placodontia, because those are rounded and flat elements, with small coracoid foramen (Rieppel 1995, 2000). We can rule out Pistosaurus and Corosaurus genera; thus, the known coracoids of Pistosaurus are more plate-like bones with expanded medial symphysis (Sues 1987; Rieppel 1998), while Corosaurus has rectangular coracoids with less prominent constriction in the middle part (Storrs 1991). Among eosauropterygians, these coracoids mostly resemble those of nothosauroids (Rieppel 1994a; Lin et al. 2017).

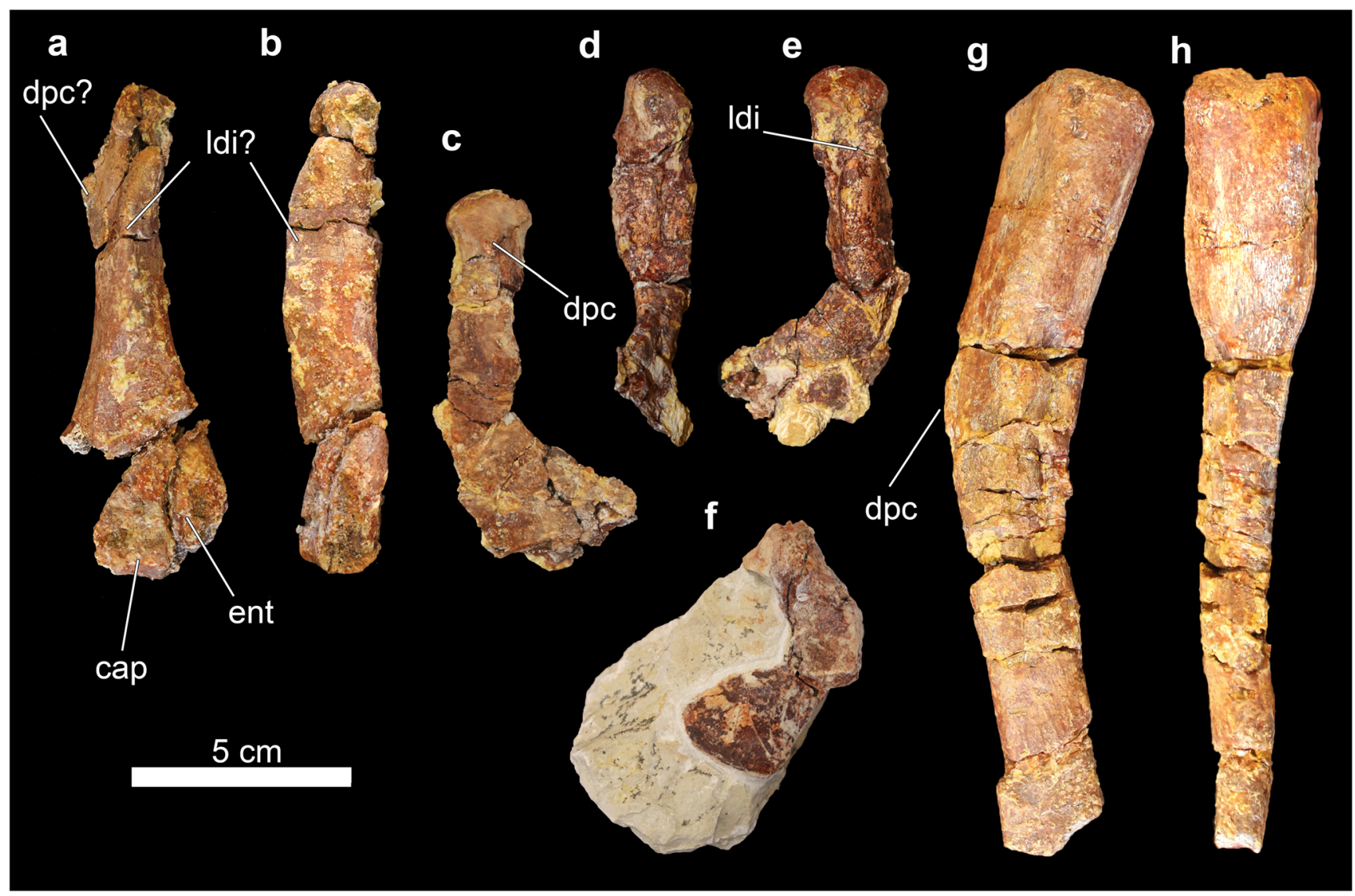

Fig. 16 Sauropterygia indet. humeri from the Middle Triassic 'Construction site' of Villány, southern Hungary. a-b 'Morphotype-1' humerus (PAL 2019.217.1.) in dorsal and in postaxial view. c-e 'Morphotype-2' humerus (PAL 2019.206.1.) in ventral, postaxial and dorsal view. f 'Morphotype-2' humerus (PAL 2019.207.1.) in dorsal view. $\mathbf{g}-\mathbf{h}$ 'Morphotype-3' humerus (PAL 2019.194.1.) in dorsal and in postaxial view. Anatomical abbreviations: cap capitellum, $d p c$ deltopectoral crest, ent entepicondyle, ldi latissimus dorsi insertion 
The character combination present on the isolated humeri (curved shape, flat ventral side, robust angulated proximal and slightly widened distal epiphyses, weakly developed epicondyles, reduced musculus latissimus dorsi insertion, moreover the weekly developed deltopectoral crest) is shared with other eosauropterygians (Rieppel 1998, 2000). However, placodontian humeri lack the entepicondylar foramen (Rieppel 1998, 2008). Within eosauropterygia, we can exclude Simosauridae, because the known simosaurid humeri have a much more robust proximal head, well-developed deltopectoral crest and strongly constricted diaphysis, and they lack an entepicondylar foramen and exhibit a more widened distal epiphysis (in the case of $S$. gaillardoti) (Rieppel 1994a, 1998; de Miguel Chaves et al. 2018a). The humeri referred to as Cymatosaurus (Rieppel 1994a) also differ from the mentioned elements with their broad and more complex distal epiphysis, constricted midshaft (Rieppel 1994a). The humeri of Pistosaurus are generally straighter, the distal end is more expanded and the whole bone is characteristically flattened (Sues 1987). The shape and curvature of these elements from Villány are most similar to the humeri of nothosaurids (Bickelmann and Sander 2008).

Because of the fragmentary preservation of the isolated ischia described here, and the generally homologous ischium morphology of eosauropterygians (Sues and Carroll 1985; Sander 1989; Rieppel 1994a, 2000; Lin et al. 2017), further classification is not possible, so we refer to them only as Eosauropterygia indet. since the ischia of placodonts are flat, plat-like rounded elements
(Rieppel 1995, 2000).

Sauropterygia Owen, 1860

Sauropterygia indet.

(Fig. 16-17)

Material: humerus 'Morphotype-1' PAL 2019.217.1.; humerus 'Morphotype-2' PAL 2019.205.1., PAL 2019.206.1., PAL 2019.207.1., PAL 2019.208.1.; humerus 'Morphotype3' PAL 2019.194.1.; femur 'Morphotype-1' PAL 2019.209.1., PAL 2019.210.1., PAL 2019.211.1., PAL 2019.212.1., PAL 2019.213.1.; femur 'Morphotype-2' PAL 2019.195.1., PAL 2019.196.1.; unidentified limb bones PAL 2019.214.1., PAL 2019.215.1., PAL 2019.216.1.

Description: Humerus 'Morphotype-1' PAL 2019.217.1. (Fig. 16(a-b)) is an incomplete (109 mm long) left humerus which is broken both on its proximal and on its distal parts. The ventral side of the bone is flat while it is dorsally domed. The diaphysis is triangular in cross-section, and the latissimus dorsi insertion and epicondyles are reduced. The shaft is constricted and separated from the epiphyses. From a dorsal view, both the pre- and postaxial margins show a similar curvature. The thickest region of the bone is close to the midshaft. On the proximal part of the postaxial side, two posterodorsally oriented canals can be identified. The bone is distally expanded and fan-shaped with a capitellum oriented medially. The distal epiphysis is broken; however, its silhouette suggests a proximally shifted entepicondyle, but an entepicondylar foramen is not recogniseable.

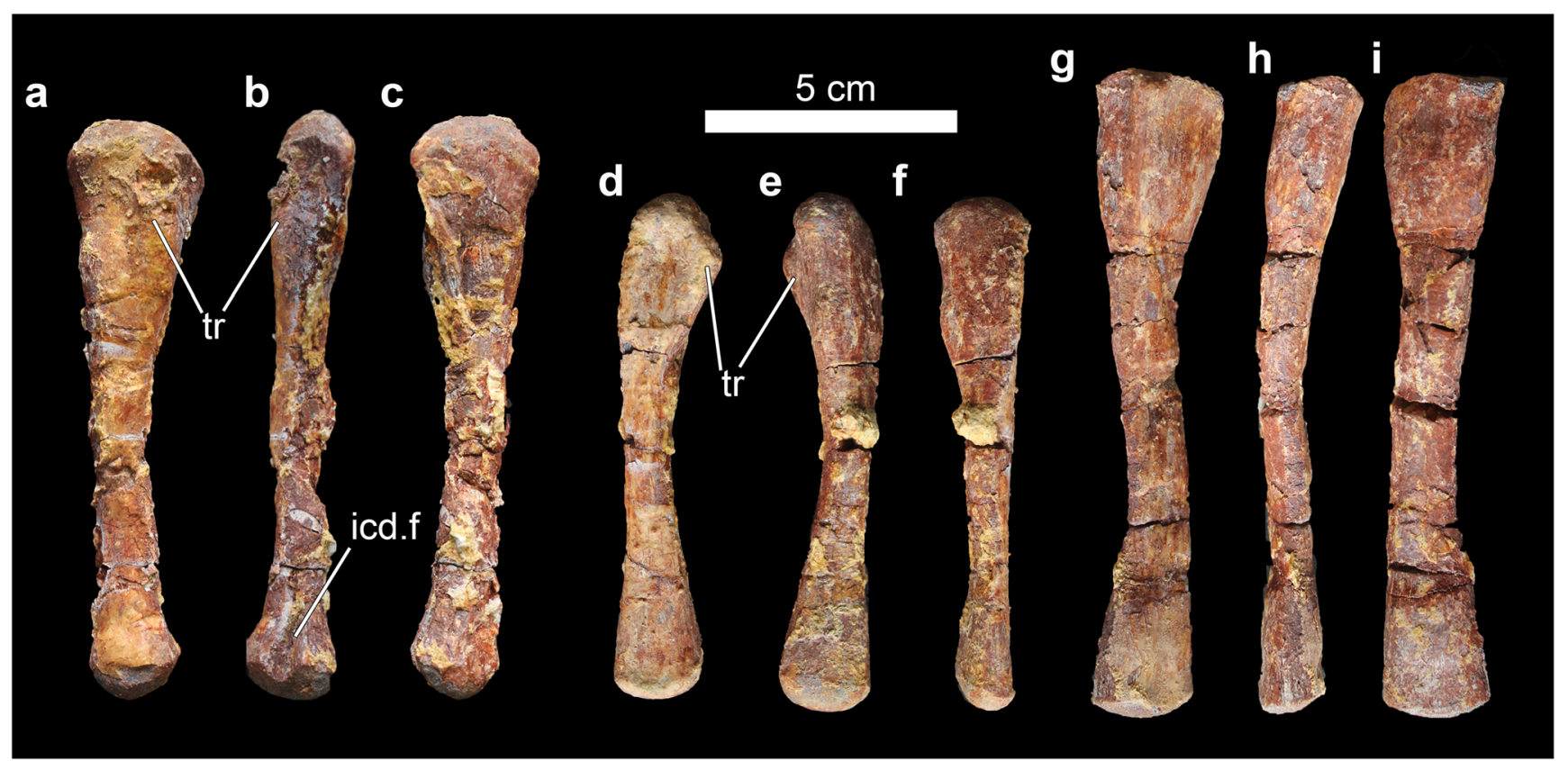

Fig. 17 Sauropterygia indet. limb bones from the Middle Triassic 'Construction site' of Villány, southern Hungary. a-c 'Morphotype-1' femur (PAL 2019.213.1.). d-f 'Morphotype-2'femur (PAL
2019.195.1.). g-i unidentified limb bone (PAL 2019.215.1.). Anatomical abbreviations: $i c d$. $f$ intercondylar fossa, $t r$ internal trochanter 


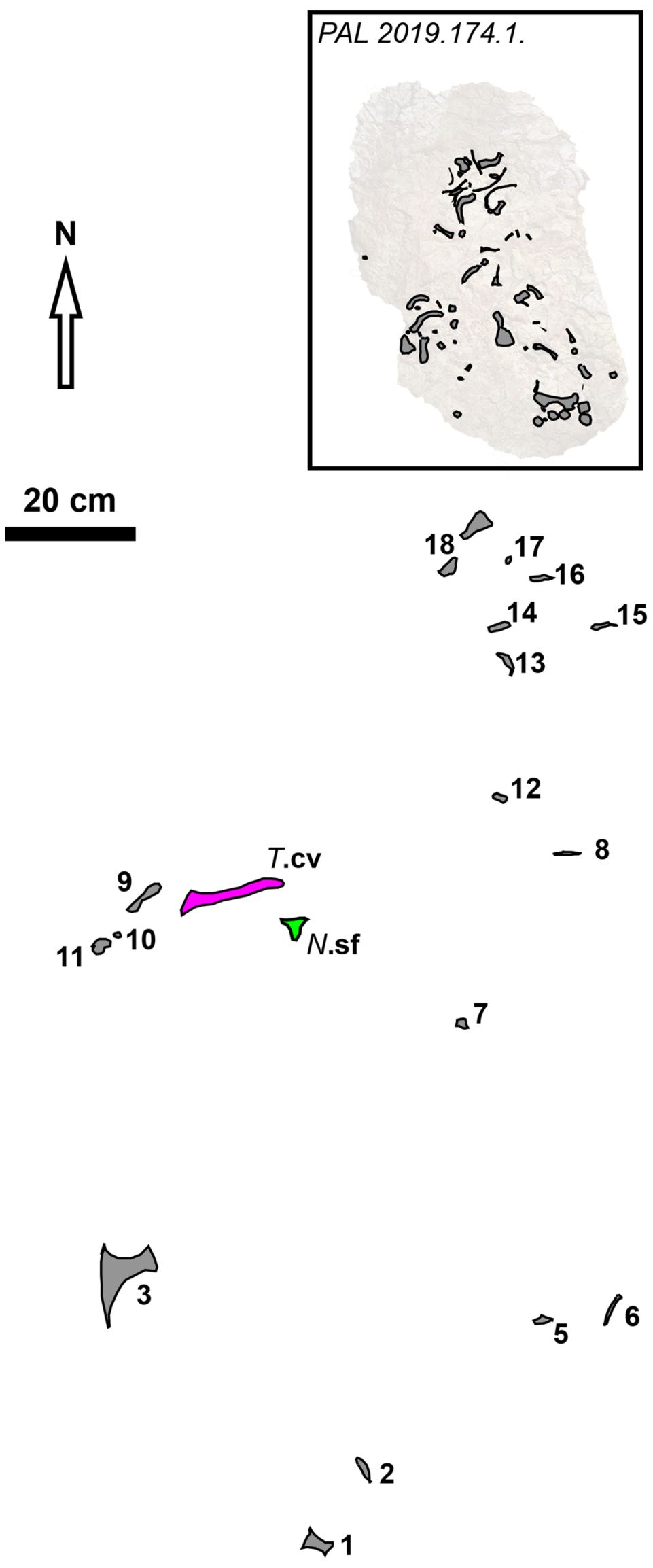

${ }^{\circ} 19$ $110^{\circ 10}$ $\nabla_{N . s f}$

$\triangle_{5} / 6$ 
Fig. 18 Mapped area of bone-bearing marl with dense bone concentration from the Middle Triassic 'Construction site' of Villány, southern Hungary. The densest bone concentration (see Fig. 19) is inside the square. Supplementary material contains a table of described specimens. Abbreviations: T.cv Tanystropheus sp. cervical vertebra, N.sf Nothosauridae indet. skull fragment (PAL 2019.156.1)

In contrast, humeri of 'Morphotype-2' (Fig. 16(c-f)) (PAL 2019.205.1., PAL 2019.206.1., PAL 2019.207.1., PAL 2019.208.1.) show a more flattened and expanded (shovelshaped) distal epiphysis with reduced epicondyles. Their size ranges between 58 and $90 \mathrm{~mm}$. Distally to the bulbous proximal head, the shaft is straight, and only after a certain point starts to bend postaxially. Deltopectoral and the insertional crest for latissimus dorsi muscle are reduced. Unfortunately, the preservation of these specimens is not good enough to detect the presence of entepicondylar foramen or ectepicondylar groove.

Humerus 'Morphotype-3' PAL 2019.194.1. (Fig. 16(g-h)) is a fragmentary 178 -mm-long left humerus with a broken distal epiphysis. The ventral side of the bone is flattened, and the diaphysis is constricted and strongly curved. The postaxial margin is concave, while the preaxial margin holds a distinct protrusion, where the bone surface is rough, indicating the strong deltopectoral crest. Distally to this protrusion, the preaxial margin is distinctly straighter. The cross-section of the diaphysis is oval, dorsoventrally flattened. The proximal head is rounded in cross-section and holds a ventropreaxially flat area. The proximal top of the bone is slightly concave.

The vertebrate material from Villány contains isolated sauropterygian femora, which can be separated into two morphotypes. They are both long and slender, slightly sigmoidal, with a constricted diaphysis which is circular or oval in cross-section; moreover, on their proximal epiphysis, the internal trochanter is reduced, and the intertrochanteric fossa is absent or shallow. In the case of 'Morphotype-1' femora (PAL 2019.209.1., PAL 2019.210.1., PAL 2019.211.1., PAL 2019.212.1., PAL 2019.213.1.) (Fig. 17(a-c)), both the proximal and distal ends of the bone are convex, the distal femoral condyles are not prominent, equisised, and the distal epiphysis has a globular shape. The length of the whole specimens in this category ranges between 109 and $188 \mathrm{~mm}$; however, the largest femur from Villány (PAL 2019.209.1.) is only fragmentary and it is $200 \mathrm{~mm}$ long. In a comparison, 'Morphotype-2' femora (Fig. 17(d-f)) (PAL 2019.195.1., PAL 2019.196.1.) are slightly different with their fan-shaped distal epiphysis twisted when compared to the proximal head. They are 107 and $106 \mathrm{~mm}$ long.

Other isolated limb bones from Villány (PAL 2019.214.1., PAL 2019.215.1., PAL 2019.216.1.) have slightly concave proximal and slightly convex distal ends (Fig. 17(g-i)). The sigmoidal shaft region is long and slender and a low ridge is present on the (probable) proximal head, which may represent the reduced internal trochanter. There is no sign of an intertrochanteric fossa. On the (probable) distal epiphysis, a shallow depression is present. The distal epiphysis is expanded, but not twisted, and its largest width is parallel to the proximal heads expansion. The length of the whole bones ranges between 122 and $127 \mathrm{~mm}$.

Discussion: Isolated humeri described here exhibit characters that are present in all sauropterygians (curved shape, reduced epicondyles, and latissimus dorsi insertion); however, the bones are too fragmentary, and given that only a further histological investigation could prove their close taxonomic position (Klein 2010). The morphology of PAL 2019.217.1. ('Morphotype-1') is more plesiomorphic than the humeri of nothosaurs, and the fan-shaped expanded distal epiphysis makes it somewhat similar to the 'pachypleurosaur' morphotype described by Klein (2010), which morphology could refer to both pachypleurosaur or basal pistosaur origin. Nevertheless, the diaphysis of PAL 2019.217.1. is triangular in cross-section, which is more similar to the humerus of nothosaurs (Bickelmann and Sander 2008; Klein 2010). Some larger placodonts also have similar fan-shaped distal epiphysis, but those are more robust and simple bones with more concave postaxial margin (Rieppel 1994a). The lack of entepyicondylar foramen could refer to its placodontian origin; however, this character is also present in the case of other sauropterygians (e.g. Pistosaurus) (Rieppel 1998). Similarly, due to that the humeri belonging to 'Morphotype-2' are too incomplete, and the morphology of distal epiphysis, especially the presence or absence of entepicondylar foramen is uncertain, we only identify them as Sauropterygia indet. The PAL 2019.194.1. ('Morphotype-3') humerus with its constricted, dorsoventrally slightly flattened, distinct diaphysis, and with its overhanging deltopectoral crest is quite similar to simosaurid humeri (Rieppel 1994a; de Miguel Chaves et al. 2018a).

The isolated femora described here show simple characters typical to this group, e.g. sigmoidally curved femoral shaft, reduced condyles, reduced internal trochanter, and absent intertrochanteric fossa (Rieppel 1998). Unfortunately, they are not diagnostic enough for closer taxonomic discussion. The appearance of these elements from Villány is highly similar to the morphology of the femora of eosauropterygians (Rieppel 1994a; Klein 2010); however, some newly described Cyamodontoidea Nopcsa, 1923 also had similar femora (see Wang et al. 2019: Fig. 7). The other mentioned unidentified limb bones are somewhat similar to the herein described sauropterygian femora. However, these bones also resemble the morphology of eosauropterygian metacarpals (see Rieppel 1994a: Fig. 32).

\section{Taphonomical observations and a probable partial eosauropterygian skeleton}

The vast majority of the skeletal elements from the 'Construction site' in Villány are isolated, although local 
concentrations of disarticulated bones were observed, too. Many elements with preserved slender spines, or in situ teeth, suggest that most of the bones did not suffer significant abrasion before they were buried in the sediment (Ősi et al. 2013; Botfalvai et al. 2019).

Since the bone-bearing layers are tectonised and sometimes slightly folded, moreover, because they are dipping to the south (with $40-50^{\circ}$ ), the surface and boundary of the layers was not always traceable, making the bone-mapping impossible in many times. In one case (during the fieldwork in 2016), when the bone concentration on a detectable level was exceptional (in the 14th layer, see Fig. 3), a bone map was drawn about a $4-\mathrm{m}^{2}$ area (Fig. 18). In the case of this part, the bonebearing marl covered a thin layer of a reddish calcareous mudstone, claystone. A significant (northern) part of this area (Fig. 19) was fixed and transported in one slab (PAL 2019.174.1.) to the Hungarian Natural History Museum. On the mapped surface (Fig. 18), completely disarticulated elements from different specimens and multiple taxa have been

a

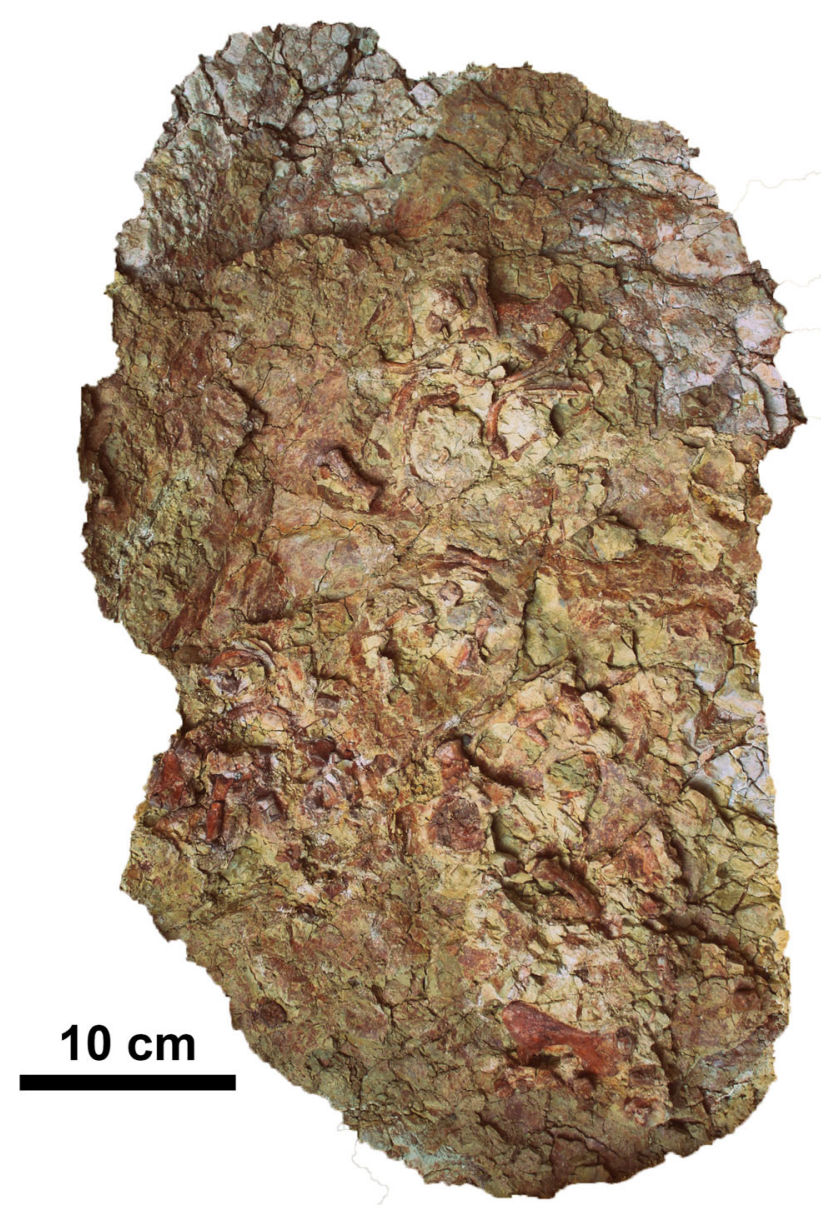

Fig. 19 Slab (PAL 2019.174.1.) with probable associated eosauropterygian elements from the Middle Triassic 'Construction site' of Villány, southern Hungary. a Overall picture, b technical drawing. uncovered. The Supplementary Material contains a table of mentioned specimens. Besides the many poorly preserved or non-diagnostic bone fragment (Fig. 18: 1, 2, 4, 5, 6, 7, 8, 10, $11,13,14,15,16,17,19)$, a cervical vertebra of Tanystropheus sp. (Ösi et al. 2020) (Fig. 18: T.cv) and the previously mentioned Nothosauridae indet. skull fragment (PAL 2019.156.1.-Fig. 18: N.sf) have been found.

The northern section of this mapped area with the slab PAL 2019.174.1. is the densest in bones in a similar small size. Besides unicipital dorsal and sacral ribs and vertebral centra, a coracoid, a limb element (probably radius), two incomplete ischium and other bone fragments are situated here.

Close to this bone concentration, an additional fragmentary long bone (probably femur) (PAL 2019.184.1.-Fig. 18: 9) and fragmentary girdle elements (PAL 2019.185.1.-Fig. 18: 18 , in two pieces) were found. The morphology of vertebral centra (with cruciform/butterfly shaped platforms) and a coracoid with a strongly waisted morphology suggests they eosauropterygian affinity (Rieppel 1998, 2000), and there is

\section{b}

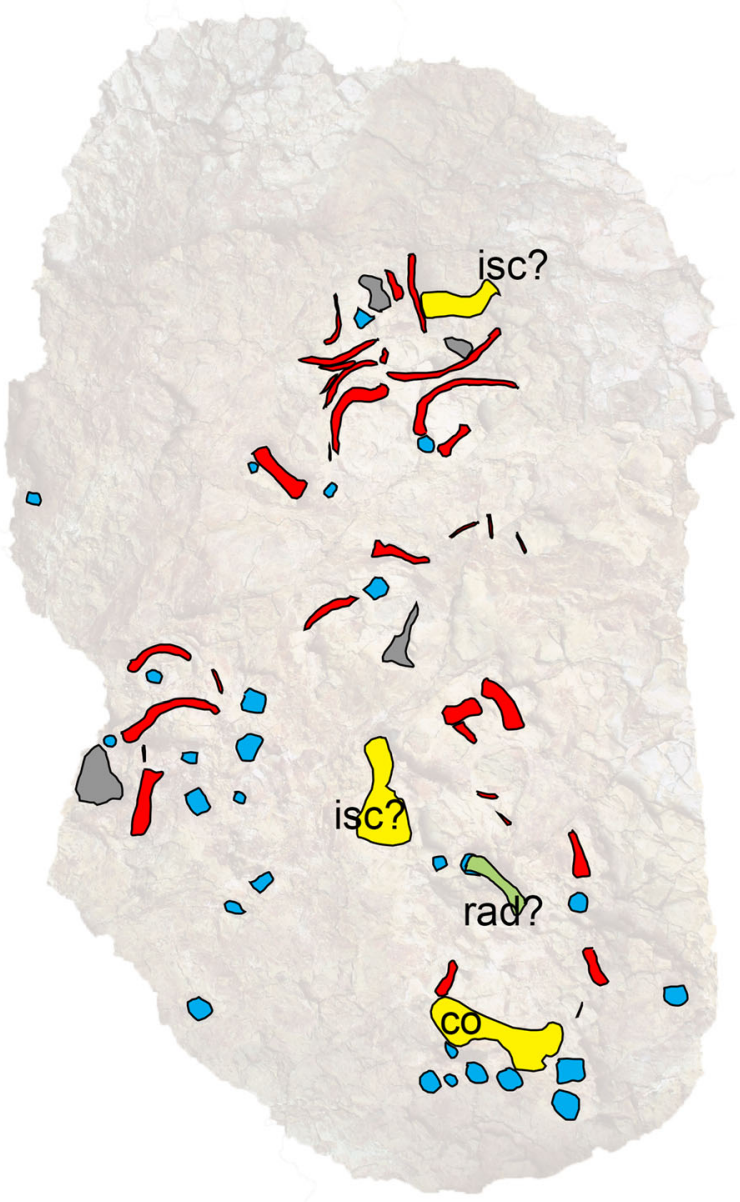

Abbreviations: co coracoid, isc ischium, rad radius. Colours: grey unidentified bone fragment, blue vertebral centra, yellow girdle element, red rib, green limb element 
a chance that the similarly small-sized fragmentary femur and girdle element fragments belong to this bone concentration. However, an isolated ischium (PAL 2019.187.1.-Fig. 18: 3) was found in the proximity of these elements, which represents a larger size class in compared to the abovementioned remains on the mapped area (Fig. 18). Moreover, it is also noteworthy that the Nothosauridae indet. skull fragment (PAL 2019.156.1.-Fig. 18: N.sf) was in the proximity of this bone concentration, and since it represents a small-sized specimen, maybe the numerous postcranial element belonged to this cranium and this area shows an associated skeleton mixed with some additional isolated bones from other specimens and species.

Except for the only one associated material of PAL 2019.174.1., all other bones are isolated, which suggests rather allochthonous than parautochtonous nature for the discovered assemblage. However, the well-preserved condition of many fragile skeletal parts and the overall lack of abrasion probably indicates that most of the material represents animals living not far from the depositional area (subtidal to peritidal zone of the inner ramp environment), and their disarticulated remains were buried only after a short period of transportation. Considering these, the vertebrate material from the 'Construction site' represents an attritional assemblage, which accumulated through a longer period of time as the results of natural mortality.

The dominant sedimentation on the carbonatic ramp of the Villány area - with high production of carbonatic mud without reef biota (Török 1998) — during the Middle Triassic was similar to the Muschelkalk facies of the Germanic Basin, where the articulated specimens are also very rare (Rieppel 2000; Klein et al. 2015).

\section{Faunal composition}

Based on the fossils discussed herein, the vertebrate material from Villány contains several different eosauropterygian taxa. The presence of simosaurids is suggested by characteristic neural arches and vertebra; moreover, several non-diagnostic, fragmentary remains (such as a mandible fragment, and humerus) may belong to this taxon. Based on the vertebra and neural arches with highly elongated neural spines, Nothosaurus genus is also known from the locality; these remains are similar to those of Nothosaurus mirabilis. Besides them, additional cranial material suggests the occurrence of another small-sized nothosaurid. Also, based on a fragmentary humerus (PAL 2019.217.1.), a further sauropterygian taxon with uncertain affinities might have inhabited this area.

The small fragmentary mandible (PAL 2019.153.1.) is comparable to the previously described - but significantly larger-Nothosaurus sp. mandible from Villány (Ösi et al.
2013). It cannot be excluded that this fragmentary mandible described here belonged to a juvenile specimen of an otherwise large-bodied species, but it has several common features with the small-sized $N$. marchicus as well (Rieppel and Wild 1996). Similarly, the fragmentary nothosaurid crania presented here show some similarities with the skulls of $N$. marchicus, but the preservational condition of these remains is not good enough for precise taxonomic investigation. The presence of several different sized eosauropterygian taxa from the same region and distinct time interval is not without precedent: a diverse system of trophic specialisation is known from many localities of the shallow marine areas of Tethys and surrounding basins (Rieppel 2000, 2002; Liu et al. 2014). The eosauropterygian assemblage described herein resembles that of the Bihor Mountains mentioned by Jurcsák (1987). Among the adjacent palaeogeographical regions, the coexistence of simosaurids with small-to-large-sized nothosaurids was also reported from the Anisian-Ladinian of the Germanic Basin (Rieppel and Wild 1996; Hagdorn and Rieppel 1999).

\section{Conclusions}

The aquatic reptile material presented here provides new important information about the Middle Triassic fauna of a previously not well-documented region of the Eurasian shelf. The assemblage, collected from the bone-yielding marl and dolomarl beds of the Middle Triassic Templomhegy Dolomite Member in the last 8 years, contains several cranial and postcranial elements of different sauropterygian taxa. The occurrence of Nothosaurus sp. is supported by vertebrae with highly elongated neural spines. Based on fragmentary cranial remains, a small-sized nothosaurid is also present in the material. Characteristic neural arches suggest the presence of Simosauridae in the fauna. The eosauropterygian assemblage from Villány resembles the previously described Triassic materials from the Germanic Basin and from the Bihor Mountains (northwestern Romania).

Supplementary Information The online version contains supplementary material available at https://doi.org/10.1007/s12549-020-00480-x.

Acknowledgements We thank Dennis F.A.E Voeten and Carlos de Miguel Chaves for their constructive and critical reviews that improved our manuscript. We are grateful for the help and advice of Krisztina Rákóczy, Gábor Botfalvai, Nicole Klein, József Pálfy, István Szente, Attila Vörös, János Haas, Viktor Karádi, Edina Prondvai, Emília Pozsgai, Dóra Csengődi, Kinga Gere and László Makádi. We would like to thank Erika Posmosanu and Márton Venczel for the access to the Triassic vertebrate collection of Tarii Crisurilor Museum (Oradea). We are thankful for the essential field and preparation work of Réka Kalmár, János Magyar and all of the members ot the Villány excavations. This research was granted by the Human Capacities Grant Management Office (EMET) of the Hungarian Ministry of Human Capacities (M. Segesdi - 
NTP-NFTÖ-16-0257; National Talent Support Program Scholarship), the National Research, Development, and Innovation Office-NKFIH (A. ÖsiOTKA K 116665, K 131597) and the ELTE Dinosaur Research Group.

Funding Open Access funding provided by Eötvös Loránd University. Research was funded by the Human Capacities Grant Management Office (EMET) of the Hungarian Ministry of Human Capacities (M. Segesdi-NTP-NFTÖ-16-0257; National Talent Support Program Scholarship), the National Research, Development and Innovation Office-NKFIH (A. Ösi-OTKA K 116665, K 131597) and the ELTE Dinosaur Research Group.

Data availability All data generated or analysed during this study are included in this published article and its supplementary information files.

\section{Compliance with ethical standards}

Conflict of interest The authors declare that they have no conflict of interest.

Open Access This article is licensed under a Creative Commons Attribution 4.0 International License, which permits use, sharing, adaptation, distribution and reproduction in any medium or format, as long as you give appropriate credit to the original author(s) and the source, provide a link to the Creative Commons licence, and indicate if changes were made. The images or other third party material in this article are included in the article's Creative Commons licence, unless indicated otherwise in a credit line to the material. If material is not included in the article's Creative Commons licence and your intended use is not permitted by statutory regulation or exceeds the permitted use, you will need to obtain permission directly from the copyright holder. To view a copy of this licence, visit http://creativecommons.org/licenses/by/4.0/.

\section{References}

Araújo, R., \& Correia, F. (2015). Soft-tissue anatomy of the Plesiosaur pectoral girdle inferred from basal Eosauropterygia taxa and the extant phylogenetic bracket. Palaeontologia Electronica, 18.1(8A), 1-32. https://doi.org/10.26879/446.

Bardet, N., Falconnet, J., Fischer, V., Houssaye, A., Jouve, S., Pereda Suberbiola, X., Pérez-García, A., Rage, J. C., \& Vincent, P. (2014). Mesozoic marine reptile palaeobiogeography in response to drifting plates. Gondwana Research, 26(3-4), 869-887. https://doi.org/10. 1016/j.gr.2014.05.005.

Baur, G. (1887-1890). Pistosauridae Baur. In K. A. Zittel (Ed.), Handbuch der Palaeontologie, Vol. 3. R (pp. 498-499). Oldenbourg: München.

Baur, G. (1889). Palaeohatteria Credner, and the Proganosauria. American Journal of Science, 3(37), 310-313. https://doi.org/10. 2475/ajs.s3-37.220.310.

Bérczi-Makk, A., Konrád, G. Y., Rálisch-Felgenhauer, E., \& Török, Á. (2004). Tisza Mega-unit. In J. Haas (Ed.), Geology of Hungary, Triassic (pp. 303-360). Budapest: ELTE Eötvös Press. [In Hungarian]

Bickelmann, C., \& Sander, P. M. (2008). A partial skeleton and isolated humeri of Nothosaurus (Reptilia:Eosauropterygia) from Winterswijk, the Netherlands. Journal of Vertebrate Paleontology, 28(2), 326-338. https://doi.org/10.1671/0272-4634(2008)28[326: APSAIH]2.0.CO;2.

Bleahu, M., Bordea, S., Panin, S., Stefanescu, M., Sikic, K., Haas, J., et al. (1994). Triassic facies types, evolution and paleogeographic relations of the Tisza Megaunit. Acta Geologica Hungarica, 37(34), $187-234$

Bodor, E. R., \& Makádi, L. (2016). Triász szórványleletek az MFGI gyűjteményéből. In M. Bosnakoff \& A. Virág (Eds.), Magyar Óslénytani Vándorgyülés - 19th Annual Meeting of Hungarian Paleontologists (pp. 8-9). Budapest: Hungarian Geological Society. [In Hungarian]

Bóna, J. (1976). Villányi-hegységi Triász Conodonták - Triadische Conodonten aus dem Villányer Gebirge. Geologica Hungarica Series Geologica, 17, 231-253.

Botfalvai, G., Győri, Ó., Pozsgai, E., Farkas, I. M., Sági, T., Szabó, M., \& Ösi, A. (2019). Sedimentological characteristics and paleoenvironmental implication of Triassic vertebrate localities in Villány (Villány Hills, Southern Hungary). Geologica Carpathica, 70(2), 135-152. https:// doi.org/10.2478/geoca-2019-0008.

Case, E. C. (1936). A nothosaur from the Triassic of Wyoming. University of Michigan Contributions from the Museum of Paleontology, 5(1), 1-36.

Čerňanský, A., Klein, N., Soták, J., Olšavský, M., Šurka, J., \& Herich, P. (2018). A Middle Triassic pachypleurosaur (Diapsida: Eosauropterygia) from a restricted carbonate ramp in the Western Carpathians (Gutenstein Formation, Fatric Unit): paleogeographic implications. Geologica Carpathica, 69(1), 3-16. https://doi.org/10.1515/geoca2018-0001.

Cope, E. D. (1871). The systematic arrangement of the Reptilia. Proceedings of the American Association for the Advancement of Science, 19, 226-247.

Csontos, L., \& Vörös, A. (2004). Mesozoic plate tectonic reconstruction of the Carpathian region. Palaeogeography, Palaeoclimatology, Palaeoecology, 210(1), 1-56. https://doi.org/10.1016/j.palaeo. 2004.02.033.

Curioni, G. (1847). Cenni sopra un nuovo saurio fossile dei monti di Perledo suI Lario e suI terreno che 10 racchiude. Giornale del' J.R. Instituto Lombardo di Scienze, Lettre ed Arti, 16, 159-170.

Dalla Vecchia, F. M. (2006). A new sauropterygian reptile with plesiosaurian affinity from the Late Triassic of Italy. Rivista Italiana di Paleontologia e Stratigrafia, 112(2), 207-225.

Feist-Burkhardt, S., Götz, A. E., Szulc, J., Borkhataria, R., Geluk, M., Haas, J., et al. (2008). Triassic. In T. McCann (Ed.), The geology of Central Europe (pp. 749-822). London: The Geological Society.

Fritsch, K. v. (1894). Beitrag zur Kemlhus der Saurier des Halle'schen unteren Muschelkalkes. Abhandlungen der Naturforschenden Gesellschaft zu Halle, 20, 273-302.

Gere, K., Scheyer, T. M., Makádi, L., \& Ösi, A. (2020). Placodont remains (Sauropsida, Sauropterygia) from the Triassic of Hungary (Transdanubian Range Unit and Villány Mountains). Palaeobiodiversity and Palaeoenvironments, 100(4), 1047-1063.

Haas, G. (1980). Ein Nothosaurier-Schadel aus dem Muschelkalk des Wadi Ramon (Negev, Israel). Annalen des Naturhistorischen Museums Wien, 83, 119-125.

Haas, J., \& Péró, C. (2004). Mesozoic evolution of the Tisza Mega-unit. International Journal of Earth Sciences, 93, 297-313. https://doi. org/10.1007/s00531-004-0384-9.

Hagdorn, H., \& Rieppel, O. (1999). Stratigraphy of marine reptiles in the Triassic of central Europe. Zentralblatt für Geologie und Palaontologie, Teil I, 651-678.

Houssaye, A. (2009). "Pachyostosis" in aquatic amniotes: a review. Integrative zoology, 4, 325-340. https://doi.org/10.1111/j.17494877.2009.00146.x

Huene, F. v. (1948). Simosaurus and Corosaurus. American Journal of Science, 246, 41-43.

Huxley, T. H. (1864). Lectures on the elements of comparative anatomy on the classification of animals and on the vertebrate skull. London: John Churchill \& Sons. 
Iordan, M. (1993). Triassic brachiopods from Romania. In J. Pálfy \& A. Vörös (Eds.), Mesozoic brachiopods of Alpine Europe (pp. 49-58). Budapest: Hungarian Geological Society.

Jaekel, O. (1901). Reste eines neuen Placodontiden aus dem unteren Keuper von Veszprém am Plattensee in Ungarn. Zeitschrift der Deutschen Geologischen Gesellschaft, 53, 56-57.

Jaekel, O. (1902a). Über Placochelys n. g. und ihre Bedeutung für die Stammesgeschichte der Schildkröten. Neues Jahrbuch für Mineralogie, Geologie und Palaontologie, Abhandlungen, 1, 127144.

Jaekel, O. (1902b). Wirbeltierreste aus der Trias des Bakonyerwaldes. In Resultate der wissenschaftlichen Erforschung des Balatonsees, Palaontologischer Anhang. Victor Hornyanszky, 1/1, 4-17.

Jaekel, O. (1907). Placochelys placodonta aus der Obertrias des Bakony. Resultate der wissenschaftlichen Erforschung des Balatonsees. In Palaontologischer Anhang. Victor Hornyanszky, 3/8, 1-91.

Jurcsák, T. (1973). Date noi asupra reptilelor fosile de virsta mezozoica din transilvania. NYMPHAEA Folia naturae Bihariae (Oradea), 1, 245-261.

Jurcsák, T. (1976). Noi descoperiri de reptile fosile în triasicul de la Alesd. NYMPHAEA Folia naturae Bihariae (Oradea), 4, 67-105.

Jurcsák, T. (1987). Triassic reptilian fauna from Bihor, Romania. In P. M. Currie \& H. E. Coster (Eds.), Fourth symposium on Mesozoic terrestrial ecosystems, short papers (pp. 125-128). Drumheller, Alta, Canada: Tyrrell Museum of Palaeontology.

Klein, N. (2010). Long bone histology of Sauropterygia from the lower Muschelkalk of the Germanic Basin provides unexpected implications for phylogeny. PLoS One, 5(7), e11613. https://doi.org/10. 1371/journal.pone.0011613.

Klein, N., Voeten, D. F. A. E., Lankamp, J., Bleeker, R., Sichelschmidt, O. J., Liebrand, M., Nieweg, D. C., \& Martin Sander, P. (2015). Postcranial material of Nothosaurus marchicus from the Lower Muschelkalk (Anisian) of Winterswijk, the Netherlands, with remarks on swimming styles and taphonomy. Paläontologische Zeitschrift, 89(4), 961-981. https://doi.org/10.1007/s12542-0150273-5.

Klein, N., Sander, P. M., Krahl, A., Scheyer, T. M., \& Houssaye, A. (2016). Diverse aquatic adaptations in Nothosaurus spp. (Sauropterygia) - inferences from humeral histology and microanatomy. PLoS One, 11(7), 1-30. https://doi.org/10.1371/journal.pone. 0158448 .

Koken, E. (1893). Beitriige zur Kenntnis der Gattung Nothosaurus. Zeitschrift der Deutschen Geologischen Gesellschaft, 45, 337-377.

Kovács, S., Bóna, J., \& Rálisch-Felgenhauer, E. (2005). Middle Anisian (Pelsonian) platform conodonts from the Triassic of the Villány Hills, South Hungary. Acta Geologica Hungarica, 48(1), 107-115.

Li, J.-L., Liu, J., \& Rieppel, O. (2002). A new species of Lariosaurus (Sauropterygia: Nothosauridae) from Triassic of Guizhou, Southwest China. Vertebrata PalAsiatica, 40, 114-126.

Lin, W.-B., Jiang, D.-Y., Rieppel, O., Motani, R., Ji, C., Tintori, A., Sun, Z. Y., \& Zhou, M. (2017). A new specimen of Lariosaurus xingyiensis (Reptilia, Sauropterygia) from the Ladinian (Middle Triassic) Zhuganpo Member, Falang Formation, Guizhou, China. Journal of Vertebrate Paleontology, 37(2), e1278703. https://doi. org/10.1080/02724634.2017.1278703.

Liu, J., Hu, S., Rieppel, O., Jiang, D., Benton, M. J., Kelley, N. P., Aitchison, J. C., Zhou, C. Y., Wen, W., Huang, J. Y., Xie, T., \& Lv, T. (2014). A gigantic nothosaur (Reptilia: Sauropterygia) from the Middle Triassic of SW China and its implication for the Triassic biotic recovery. Scientific Reports, 4, 7142. https://doi.org/10.1038/ srep07142.

Meyer, H. v. (1839). Mittheilung, an Professor Bronn gerichtet. Neues Jahrbuch fur Mineralogie, Geognosie, Geologie und Petrefaktenkunde, 559-560.
Meyer, H. v. (1842). Simosaurus, die Stumpfschnauze, ein Saurier aus dem Muschelkalke von Luneville. Neues Jahrbuch fur Mineralogie, Geognosie, Geologie und Petrefaktenkunde, 184-197.

Meyer, H. v. (1847-1855). Die Saurier des Muschelkalkes mit Rücksicht auf die Saurier aus buntem Sandstein und Keuper. In H. Keller (Ed.), Zur Fauna der Vorwelt. Frankfurt am Main: Heinrich Keller.

Miguel Chaves, C. de, Ortega, F., \& Pérez-García, A. (2018a). New highly pachyostotic nothosauroid interpreted as a filter-feeding Triassic marine reptile. Biology Letters, 14(20180130) http://rsbl. royalsocietypublishing.org/content/14/8/20180130.abstract.

Miguel Chaves, C. de, Ortega, F., \& Pérez-García, A. (2018b). Cranial variability of the European Middle Triassic sauropterygian Simosaurus gaillardoti. Acta Paleontologica Polonica, 63(2), 315-326. https://doi.org/10.4202/app.00471.2018.

Miguel Chaves, C. de, Ortega, F., \& Pérez-García, A. (2019). On the validity of the Middle Triassic sauropterygian 'Partanosaurus zitteli' and the diversity of Simosauridae. Journal of Vertebrate Paleontology, 39(5), 315-326. https://doi.org/10.1080/02724634. 2019.1704770.

Münster, G. (1834). Vorläufige Nachricht über einige neue Reptilien im Muschelkalke von Baiern. Neues Jahrbuch für Mineralogie, Geognosie, Geologie und Petrefaktenkunde, 521-527.

Nagy, E., \& Nagy, I. (1976). Triasbildungen des Villányer Gebirges. Geologica Hungarica Series Geologica, 17, 113-227.

Neenan, J. M., Klein, N., \& Scheyer, T. M. (2013). European origin of placodont marine reptiles and the evolution of crushing dentition in Placodontia. Nature Communications, 4(1621). https://doi.org/10. 1038/ncomms2633.

Neenan, J. M., Reich, T., Evers, S. W., Druckenmiller, P. S., Voeten, D. F. A. E., Choiniere, J. N., et al. (2017). Evolution of the Sauropterygian labyrinth with increasingly pelagic lifestyles. Current Biology, 27(24), 3852-3858.e3. https://doi.org/10.1016/j. cub.2017.10.069.

Nopcsa, F. (1923). Die Familien der Reptilien. Fortschritte der Geologie und Palaeontologie. Berlin: Borntraeger.

Nopcsa, F. (1928). Palaeontological notes on reptiles. Geologica Hungaria, Series Palaeontologica, 1, 3-84.

Ösi, A., Pozsgai, E., Botfalvai, G., Götz, A., E., Prondvai, E., Makádi, L., et al. (2013). First report of Triassic vertebrate assemblages from the Villány Hills (Southern Hungary). Central European Geology, 56(4), 297-335. https://doi.org/10.1556/CEuGeol.56.2013.4.2.

Ösi, A., Szabó, M., \& Botfalvai, G. (2020). Tanystropheus and other archosauromorph reptile remains from the Middle and Late Triassic of Villány (Villány Hills, Hungary). Geologica Carpatica, 71(3), 264-273. https://doi.org/10.31577/GeolCarp.71.3.5.

Owen, R. (1860). Paleontology. Edinburgh: Adam and Charles Black.

Patrulius, D., Bleahu, M., Popescu, I., \& Bordea, S. (1971). The Triassic formations of the Apuseni Mountains and of the Eastern Carpathians Bend - guidebook to field trips. In II $d$. Triassic Colloquium of the Carpatho-Balkan Geological Association. Bucharest: Institute of Geology and Geophysics.

Patrulius, D., Bleahu, M., Antonescu, E., Baltres, A., Bordea, S., Bordea, J., et al. (1979). The Triassic formations of the Bihor Autochton and Codru nappe-system (Apuseni Mounteins) - guidebook to field trips. In III d. Triassic Colloquium of the Carpatho-Balkan Geological Association. Bucharest: Institute of Geology and Geophysics.

Posmosanu, E. (2008). Notes on a Cyamodontoid maxillary from the Middle Triassic site Lugaşu de Sus (W. Romania). NYMPHAEA Folia naturae Bihariae (Oradea), 35, 27-34.

Posmosanu, E. (2013). Taphonomic analysis of the Middle Triassic marine vertebrate assemblages from Lugaşu de Sus and Peștiş (Bihor, North-Western Romania). NYMPHAEA Folia naturae Bihariae (Oradea), 40, 5-18.

Pozsgai, E., Józsa, S., Dunkl, I., Sebe, K., Thamó-Bozsó, E., Sajó, I., Dezső, J., \& von Eynatten, H. (2017). Provenance of the Upper Triassic siliciclastics of the Mecsek Mountains and Villány Hills 
(Pannonian Basin, Hungary): constraints to the Early Mesozoic paleogeography of the Tisza Megaunit. International Journal of Earth Sciences (Geologische Rundschau), 106, 2005-2024. https://doi. org/10.1007/s00531-016-1406-0.

Rálisch-Felgenhauer, E. (1981). Templomhegyi Dolomit Formáció (Templomhegy Dolomite Formation). In MÁFI Jelentés villányihegységi alapszelvények vizsgalatáról (Geological Institute of Hungary report about the study of key sections of the Villany Hills). Budapest: MÁFI 40 p. [in Hungarian]

Rálisch-Felgenhauer, E. (1985). Villányi-hegység, Villány, Templomhegyi siklóbevágás (Road-cut section on Templom Hill, Villány Hills). In Magyarország geológiai alapszelvényei (Geological key sections of Hungary). Budapest: MÁFI 5 p. [in Hungarian]

Rálisch-Felgenhauer, E., \& Török, Á. (1993). Mecsek and Villány Mountains. In J. Haas (Ed.), Triassic lithostratigraphic units of Hungary (pp. 232-260). Budapest: Hungarian Geological SurveyMOL Ltd. [in Hungarian]

Rieppel, O. (1994a). Osteology of Simosaurus gaillardoti and the relationships of stem-group Sauropterygia. Fieldiana (Geology), New Series, (28), 1-85. https://doi.org/10.5962/bhl.title.3399.

Rieppel, O. (1994b). The braincases of Simosaurus and Nothosaurus: Monophyly of the Nothosauridae (Reptilia: Sauropterygia). Journal of Vertebrate Paleontology, 14(1), 9-23. https://doi.org/ 10.1080/02724634.1994.10011535.

Rieppel, O. (1995). The genus Placodus: systematics, morphology, paleobiogeography, and paleobiology. Fieldiana (Geology), New Series, (31), 1-44.

Rieppel, O. (1997). Sauropterygia: Introduction. In J. M. Callaway \& E. L. Nicholls (Eds.), Ancient Marine Reptiles (pp. 107-119). San Diego: Academic Press.

Rieppel, O. (1998). The status of the Sauropterygian reptile genera Ceresiosaurus, Lariosaurus, and Silvestrosaurus from the Middle Triassic of Europe, Fieldiana (Geology). New Series, 38, 1-46.

Rieppel, O. (1999). Phylogeny and paleobiogeography of Triassic Sauropterygia: problems solved and unresolved. Palaeoclimatology, Palaeogeography, Palaeoecology, 153, 1-15. https://doi.org/10. 1016/S0031-0182(99)00067-X.

Rieppel, O. (2000). Sauropterygia I. Placodontia, Pachypleurosauria, Nothosauroidea, Pistosauroidea. In Handbuch der Paläoherpetologie, Teil 12A. München: Friedrich Pfeil.

Rieppel, O. (2001). A new species of Nothosaurus (Reptilia: Sauropterygia) from the Upper Muschelkalk (Lower Ladinian) of southwestern Germany. Palaeontographica Abteilung A, 263(November), 137-161.

Rieppel, O. (2002). Feeding mechanics in Triassic stem-group sauropterygians: The anatomy of a successful invasion of Mesozoic seas. Zoological Journal of the Linnean Society, 135(1), 33-63. https://doi.org/10.1046/j.1096-3642.2002.00019.x.

Rieppel, O. (2008). Paraplacodus and the phylogeny of the Placodontia (Reptilia: Sauropterygia). Zoological Journal of the Linnean Society, 130(4), 635-659. https://doi.org/10.1111/j.1096-3642. 2000.tb02204.x.

Rieppel, O., \& Hagdorn, H. (1997). Paleobiogeography of Middle Triassic Sauropterygia in Central and Western Europe. In J. M. Callaway \& E. L. Nicholls (Eds.), Ancient Marine Reptiles (pp. 121-144). San Diego: Academic Press.

Rieppel, O., \& Wild, R. (1994). Nothosaurus edingerae Schultze, 1970: diagnosis of the species and comments on its stratigraphical occurrence. Stuttgarter Beitrage fur Naturkunde, B204, 1-13.

Rieppel, O., \& Wild, R. (1996). A revision of the genus Nothosaurus (Reptilia, Sauropterygia) from the Germanic Triassic, with comments on the status of Conchiosaurus clavatus. Fieldiana (Geology), New Series, (34), 1-82.
Rieppel, O., Mazin, J.-M., \& Tchernov, E. (1999). Sauropterygia from the Middle Triassic of Makhtesh Ramon, Negev, Israel. Fieldiana (Geology), 40, 1-85.

Rieppel, O., Jinling, L., \& Jun, L. (2003). Lariosaurus xingyiensis (Reptilia: Sauropterygia ) from the Triassic of China. Canadian Journal of Earth Sciences, 40, 621-634. https://doi.org/10.1139/ e02-067.

San, K. K., Fraser, N. C., Foffa, D., Rieppel, O., \& Brusatte, S. L. (2019). The first Triassic vertebrate fossils from Myanmar: Pachypleurosaurs in a marine limestone. Acta Palaeontologica Polonica, 64(2), 357362.

Sander, P. M. (1989). The pachypleurosaurids (Reptilia: Nothosauria) from the Middle Triassic of Monte San Giorgio, (Switzerland), with the description of a new species. Philosophical Transactions of the Royal Society of London, B, (325), 561-670.

Sander, P. M., Rieppel, O., \& Bucher, H. (1997). A new pistosaurid (Reptilia: Sauropterygia) from the Middle Triassic of Nevada and its implications for the origin of the plesiosaurs. Journal of Vertebrate Paleontology, 17, 526-533.

Scheyer, T. M. (2010). New interpretation of the postcranial skeleton and overall body shape of the placodont Cyamodus hildegardis Peyer, 1931 (Reptilia, Sauropterygia). Palaeontologia Electronica, 13(2), 15A:15p http://palaeo-electronica.org/2010_2/232/index.html.

Scheyer, T. M., Neenan, J. M., Renesto, S., Saller, F., Hagdorn, H., Furrer, H., Rieppel, O., \& Tintori, A. (2012). Revised paleoecology of placodonts - with a comment on 'The shallow marine placodont Cyamodus of the central European Germanic Basin: its evolution, paleobiogeography and paleoecology' by C. G. Diedrich (Historical Biology, iFirst article, 2011, 1-19). Historical Biology, 24(3), 257 267. https://doi.org/10.1080/08912963.2011.621083.

Schmid, S. M., Bernoulli, D., Matenco, L., Schefer, S., Schuster, R., Tischler, M., \& Ustaszewski, K. (2008). The Alpine-CarpathianDinaridic orogenic system: correlation and evolution of tectonic units. Swiss Journal of Geosciences, 101, 139-183.

Schroeder, H. (1914). Wirbeltiere der Riidersdorfer Trias. Abhandlungen der Königlich Preussischen Geologischen Landesanstalt, Neue Folge, 65, 1-98.

Schultze, H.-P. (1970). Über Nothosaurus. Neubeschreibung eines Schädels aus dem Keuper. Senckenbergiana lethaea, 51, 211-237.

Segesdi, M., Ösi, A., \& Botfalvai, G. (2017). New eosauropterygian remains from the Middle Triassic of Villány, Hungary. In O. Hampe, D. Schwarz, \& M. Voss (Eds.), 8th secondary adaptation of Tetrapods to life in water (p. 47). Berlin: Museum für Naturkunde.

Shang, Q.-H. (2006). A new species of Nothosaurus from the early Middle Triassic of Guizhou, China. Vertebrata PalAsiatica, 44(3), 237-249.

Smith, J. B., \& Dodson, P. (2003). A proposal for a standard terminology of anatomical notation and orientation in fossil vertebrate dentitions. Journal of Vertebrate Paleontology, 23(1), 1-12.

Storrs, G. (1991). Anatomy and relationships of Corosaurus alcovensis (Diapsida: Sauropterygia) and the Triassic Alcova Limestone of Wyoming. Bulletin of the Peabody Museum of Natural History, $44,1-151$.

Storrs, G. (1993). Function and phylogeny in sauropterygian (Diapsida) evolution. American Journal of Science, 293A, 63-90.

Sues, H. D. (1987). Postcranial skeleton of Pistosaurus and interrelationships of the Sauropterygia (Diapsida). Zoological Journal of the Linnean Society, 90, 109-131.

Sues, H. D., \& Carroll, R. L. (1985). The pachypleurosaurid Dactylosaurus schroederi (Diapsida: Sauropterygia). Canadian Journal of Earth Sciences, 22, 1062-1608.

Szabó, M., Botfalvai, G., \& Ösi, A. (2019). Taxonomical and palaeoecological investigations of the chondrichthyan and osteichthyan fish remains from the Middle-Late Triassic deposits of the Villány Hills (southern Hungary). Geobios, 57, 111-126. https://doi.org/10.1016/j.geobios.2019.10.006. 
Szulc, J. (2000). Middle Triassic evolution of the northern Peri-Tethys area as influenced by early opening of the Tethys Ocean. Annales Societatis Geologorum Poloniae, 70, 1-48.

Tintori, A., \& Renesto, S. (1990). A new Lariosaurus from the Kalkschieferzone (Uppermost Ladinian) of Valceresio (Varese, N. Italy). Bollettino della Società Paleontologica ltaliana, 29(3), 309319.

Török, Á. (1997). Triassic ramp evolution in Southern Hungary and its similarities to Germano-type Triassic. Acta Geologica Hungarica, 40(4), 367-390.

Török, Á. (1998). A Mecsek-Villányi Egység triász képzõdményeinek rétegtana. In I. Bérczi \& Á. Jámbor (Eds.), Magyarország geológiai képzõdményeinek rétegtana (pp. 253-279). Budapest: MOL Rt., MÁFI. [in Hungarian]

Török, Á. (2000). Muschelkalk carbonates in southern Hungary: an overview and comparison to German Muschelkalk. Zentralblatt für Geologie und Paläontologie, Teil. I, (9-10), 1085-1103.

Venczel, M. (1998). Gerinces ösmaradványok kutatása Biharban. Állattani Közlemények, 83, 129-134. [in Hungarian]

Voeten, D. F. A. E., Sander, P. M., \& Klein, N. (2015). Skeletal material from larger Eusauropterygia (Reptilia: Eosauropterygia) with nothosaurian and cymatosaurian affinities from the lower
Muschelkalk of Winterswijk, the Netherlands. Paläontologische Zeitschrift, 89, 943-960. https://doi.org/10.1007/s12542-014-0250-4.

Voeten, D. F. A. E., Reich, T., Araújo, R., \& Scheyer, T. M. (2018). Synchrotron microtomography of a Nothosaurus marchicus skull informs on nothosaurian physiology and neurosensory adaptations in early Sauropterygia. PLoS One, 13(1), e0188509. https://doi.org/ 10.1371/journal.pone.0188509.

Vörös, A. (1972). A Villányi-hegység alsó és középső júra képződményeinek üledékföldtani vizsgálata. Földtani Közlöny, 102(1), 12-28. [in Hungarian]

Vörös, A. (2009). Tectonically-controlled Late Triassic and Jurassic sedimentary cycles on a peri-Tethyan ridge (Villány, southern Hungary). Central European Geology, 52(2), 125-151.

Wang, W., Li, C., \& Wu, X.- C. (2019). An adult specimen of Sinocyamodus xinpuensis (Sauropterygia: Placodontia) from Guanling, Guizhou, China. Zoological Journal of the Linnean Society, 185, 910-924.

Publisher's note Springer Nature remains neutral with regard to jurisdictional claims in published maps and institutional affiliations. 